\title{
LEVEL II SCOUR ANALYSIS FOR BRIDGE 37 (CABOTH00410037) on TOWN HIGHWAY 41, crossing the WINOOSKI RIVER, CABOT, VERMONT
}

U.S. Geological Survey Open-File Report 97-781

Prepared in cooperation with

VERMONT AGENCY OF TRANSPORTATION and

FEDERAL HIGHWAY ADMINISTRATION 


\section{LEVEL II SCOUR ANALYSIS FOR BRIDGE 37 (CABOTH00410037) on TOWN HIGHWAY 41, crossing the WINOOSKI RIVER, CABOT, VERMONT By ROBERT H. FLYNN AND LAURA MEDALIE}

U.S. Geological Survey Open-File Report 97-781

Prepared in cooperation with

VERMONT AGENCY OF TRANSPORTATION and

FEDERAL HIGHWAY ADMINISTRATION 


\title{
U.S. DEPARTMENT OF THE INTERIOR BRUCE BABBITT, Secretary
}

\author{
U.S. GEOLOGICAL SURVEY \\ Mark Schaefer, Director
}

For additional information write to:

District Chief

U.S. Geological Survey 361 Commerce Way

Pembroke, NH 03275-3718
Copies of this report may be purchased from:

U.S. Geological Survey

Branch of Information Services

Open-File Reports Unit

Box 25286

Denver, CO 80225-0286 


\section{CONTENTS}

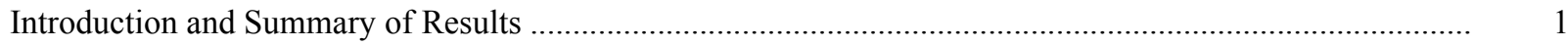

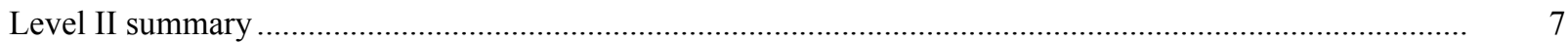

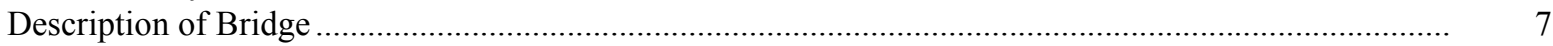

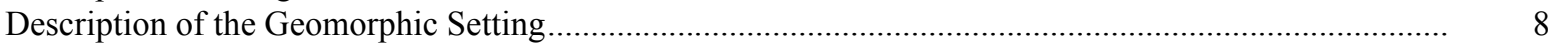

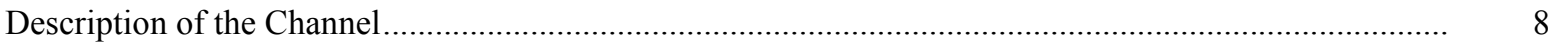

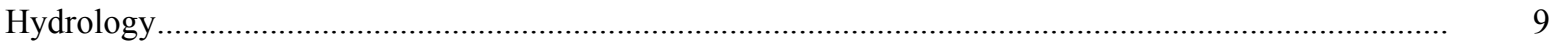

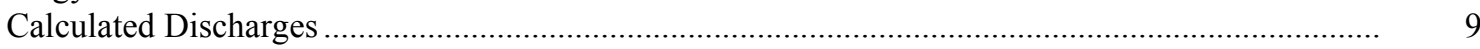

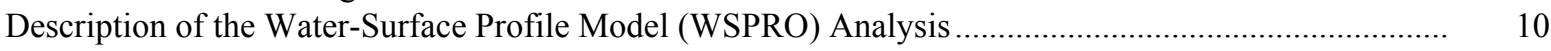

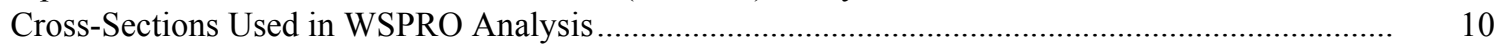

Data and Assumptions Used in WSPRO Model ..................................................................... 11

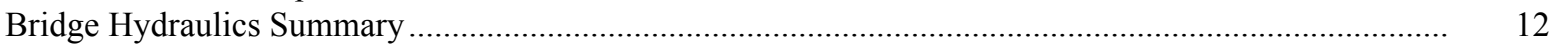

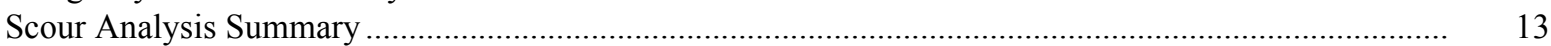

Special Conditions or Assumptions Made in Scour Analysis ...................................................... 13

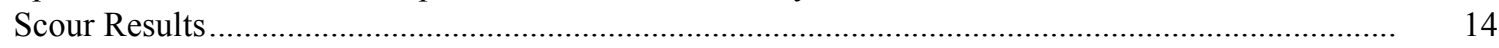

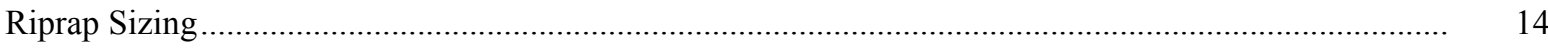

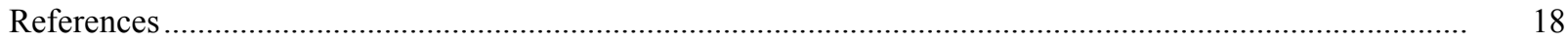

Appendixes:

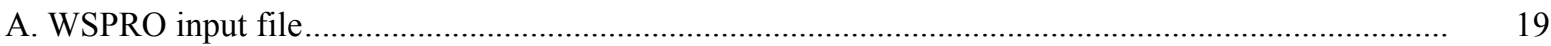

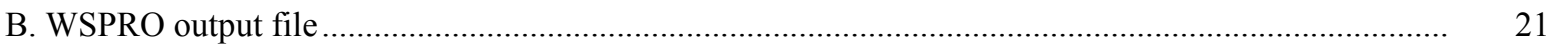

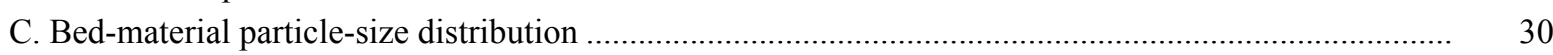

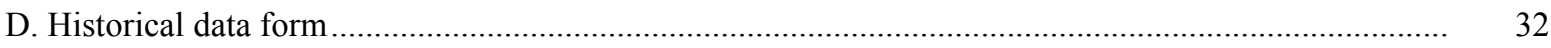

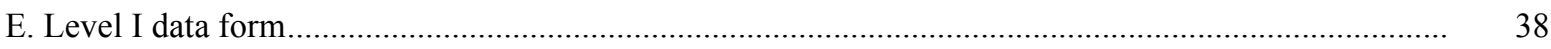

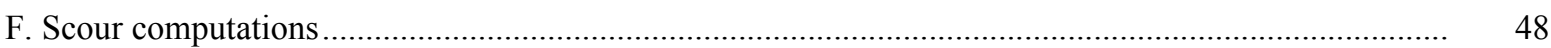

\section{FIGURES}

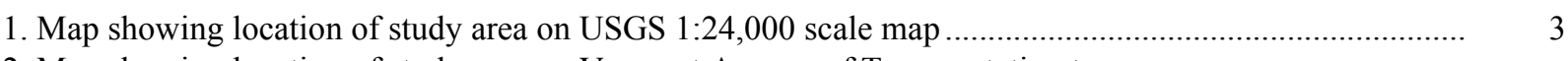

2. Map showing location of study area on Vermont Agency of Transportation town

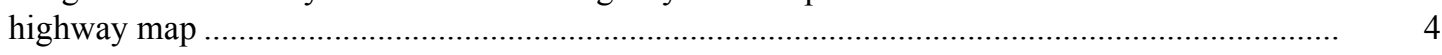

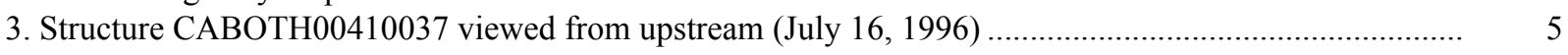

4. Downstream channel viewed from structure CABOTH00410037 (July 16, 1996)................................ 5

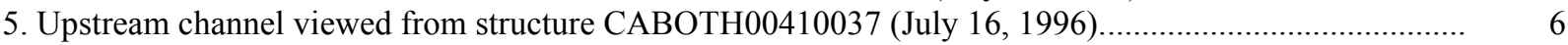

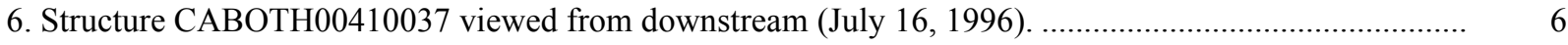

7. Water-surface profiles for the 100- and 500-year discharges at structure

CABOTH00410037 on Town Highway 41, crossing the Winooski River,

Cabot, Vermont.

8. Scour elevations for the 100- and 500-year discharges at structure

CABOTH00410037 on Town Highway 41, crossing the Winooski River,

Cabot, Vermont.

\section{3}

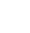

5

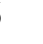




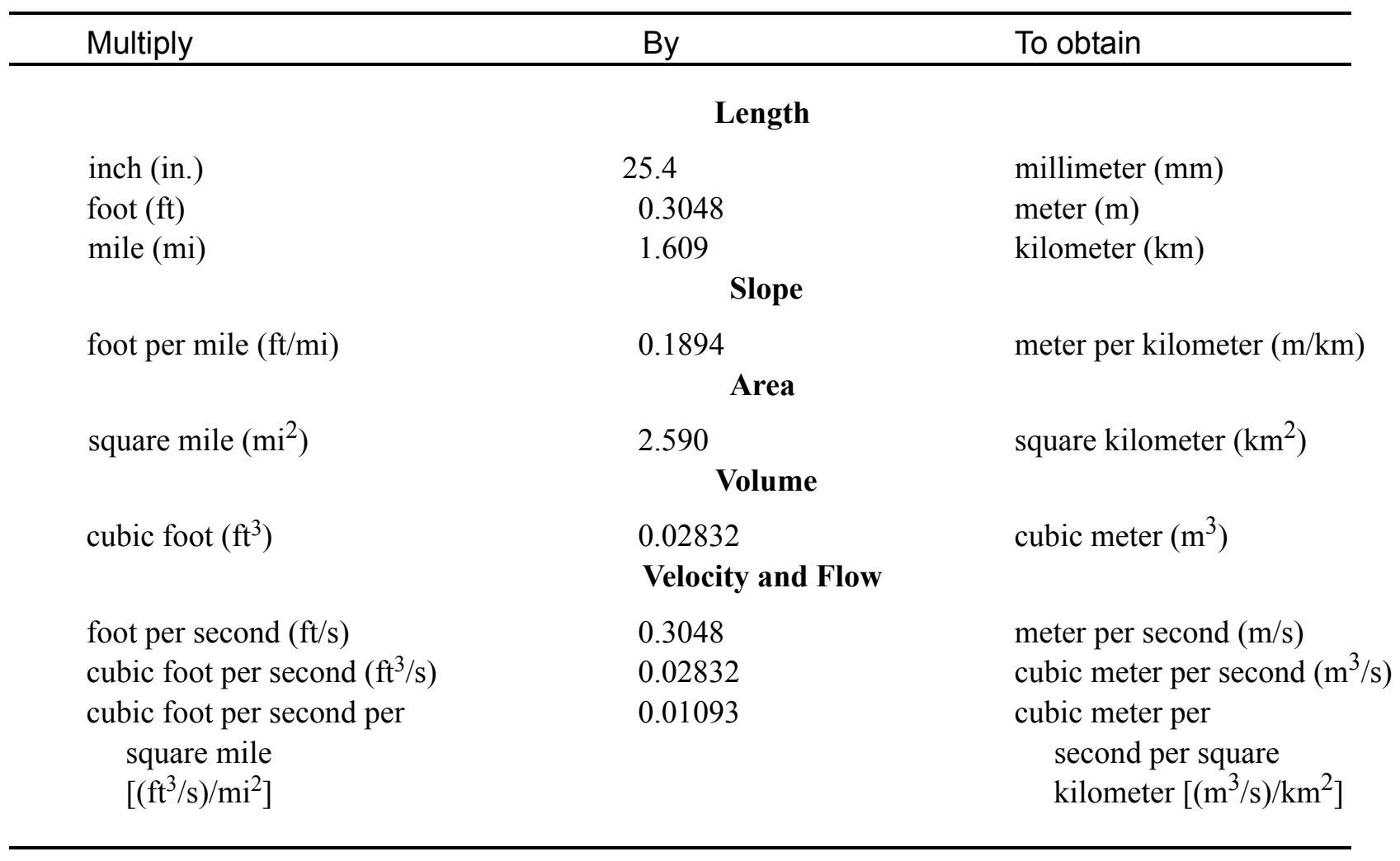

\section{OTHER ABBREVIATIONS}

$\begin{array}{lrlr}\mathrm{BF} & \text { bank full } & \text { LWW } & \text { left wingwall } \\ \mathrm{cfs} & \text { cubic feet per second } & \text { MC } & \text { main channel } \\ \mathrm{D}_{50} & \text { median diameter of bed material } & \text { RAB } & \text { right abutment } \\ \mathrm{DS} & \text { downstream } & \text { RABUT } & \text { face of right abutment } \\ \mathrm{elev} & \text { elevation } & \text { RB } & \text { right bank } \\ \mathrm{f} / \mathrm{p} & \text { flood plain } & \text { ROB } & \text { right overbank } \\ \mathrm{ft}^{2} & \text { square feet } & \text { RWW } & \text { right wingwall } \\ \mathrm{ft} / \mathrm{ft} & \text { feet per foot } & \text { TH } & \text { town highway } \\ \mathrm{JCT} & \text { junction } & \text { UB } & \text { under bridge } \\ \mathrm{LAB} & \text { left abutment } & \text { US } & \text { upstream } \\ \mathrm{LABUT} & \text { face of left abutment } & \text { USGS } & \text { United States Geological Survey } \\ \mathrm{LB} & \text { left bank } & \text { VTAOT Vermont Agency of Transportation } \\ \mathrm{LOB} & \text { left overbank } & \text { WSPRO } & \text { water-surface profile model }\end{array}$

In this report, the words "right" and "left" refer to directions that would be reported by an observer facing downstream. Sea level: In this report, "sea level" refers to the National Geodetic Vertical Datum of 1929-- a geodetic datum derived from a general adjustment of the first-order level nets of the United States and Canada, formerly called Sea Level Datum of 1929.

In the appendices, the above abbreviations may be combined. For example, USLB would represent upstream left bank. 


\title{
LEVEL II SCOUR ANALYSIS FOR BRIDGE 37 (CABOTH00410037) ON TOWN HIGHWAY 41, CROSSING THE WINOOSKI RIVER, CABOT, VERMONT
}

\author{
By Robert H. Flynn and Laura Medalie
}

\section{INTRODUCTION AND SUMMARY OF RESULTS}

This report provides the results of a detailed Level II analysis of scour potential at structure CABOTH00410037 on Town Highway 41 crossing the Winooski River (also referred to as Coit's Pond Brook), Cabot, Vermont (figures 1-8). A Level II study is a basic engineering analysis of the site, including a quantitative analysis of stream stability and scour (U.S. Department of Transportation, 1993). Results of a Level I scour investigation also are included in Appendix E of this report. A Level I investigation provides a qualitative geomorphic characterization of the study site. Information on the bridge, gleaned from Vermont Agency of Transportation (VTAOT) files, was compiled prior to conducting Level I and Level II analyses and is found in Appendix D.

The site is in the New England Upland section of the New England physiographic province in northeastern Vermont. The 21.4- $\mathrm{mi}^{2}$ drainage area is in a predominantly rural and forested basin. In the vicinity of the study site, the surface cover is primarily shrub and brushland while the immediate banks have dense woody vegetation.

In the study area, the Winooski River has an incised, straight channel with a slope of approximately $0.01 \mathrm{ft} / \mathrm{ft}$, an average channel top width of $53 \mathrm{ft}$ and an average bank height of $4 \mathrm{ft}$. The channel bed material is primarily cobbles and boulder with a median grain size $\left(\mathrm{D}_{50}\right)$ of $64.5 \mathrm{~mm}(0.212 \mathrm{ft})$. The geomorphic assessment at the time of the Level I and Level II site visit on July 16, 1996, indicated that the reach was stable.

The Town Highway 41 crossing of the Winooski River is a 29-ft-long, one-lane bridge consisting of one 26-foot span (Vermont Agency of Transportation, written communication, October 13, 1995) with four steel I-beams and a wooden deck. The opening length of the structure parallel to the bridge face is $26 \mathrm{ft}$.The bridge is supported by "laid up" granite block abutments with concrete footings. The channel is skewed approximately 35 degrees to the opening while the computed opening-skew-to-roadway is 15 degrees. The VTAOT computed opening-skew-to-roadway is zero degrees. 
The only scour protection measure observed at the site during the Level I assessment was type-2 stone fill (less than 36 inches diameter) along the entire base length of the left abutment and upstream right wingwall, along the upstream left bank and along the downstream left and right banks. Additional details describing conditions at the site are included in the Level II Summary and Appendices $\mathrm{D}$ and $\mathrm{E}$.

Scour depths and recommended rock rip-rap sizes were computed using the general guidelines described in Hydraulic Engineering Circular 18 (Richardson and others, 1995) for the 100- and 500-year discharges. In addition, the incipient roadway-overtopping and maximum free-surface flow discharges were determined and analyzed as two other potential worst-case scour scenarios. Total scour at a highway crossing is comprised of three components: 1) long-term streambed degradation; 2) contraction scour (due to accelerated flow caused by a reduction in flow area at a bridge) and; 3 ) local scour (caused by accelerated flow around piers and abutments). Total scour is the sum of the three components. Equations are available to compute depths for contraction and local scour and a summary of the results of these computations follows.

Contraction scour for all modelled flows ranged from 0.0 to $2.7 \mathrm{ft}$. The worst-case contraction scour occurred at the maximum free-surface flow (with road overflow) discharge, which was less than the 100-year discharge. Abutment scour ranged from 9.8 to $10.7 \mathrm{ft}$ along the left abutment and from 16.2 to $19.9 \mathrm{ft}$ along the right abutment. The worstcase abutment scour occurred at the 500-year discharge. Additional information on scour depths and depths to armoring are included in the section titled "Scour Results". Scouredstreambed elevations, based on the calculated scour depths, are presented in tables 1 and 2. A cross-section of the scour computed at the bridge is presented in figure 8. Scour depths were calculated assuming an infinite depth of erosive material and a homogeneous particlesize distribution.

It is generally accepted that the Froehlich and Hire equations (abutment scour) gives "excessively conservative estimates of scour depths" (Richardson and others, 1995, p. 47). Usually, computed scour depths are evaluated in combination with other information including (but not limited to) historical performance during flood events, the geomorphic stability assessment, existing scour protection measures, and the results of the hydraulic analyses. Therefore, scour depths adopted by VTAOT may differ from the computed values documented herein. 


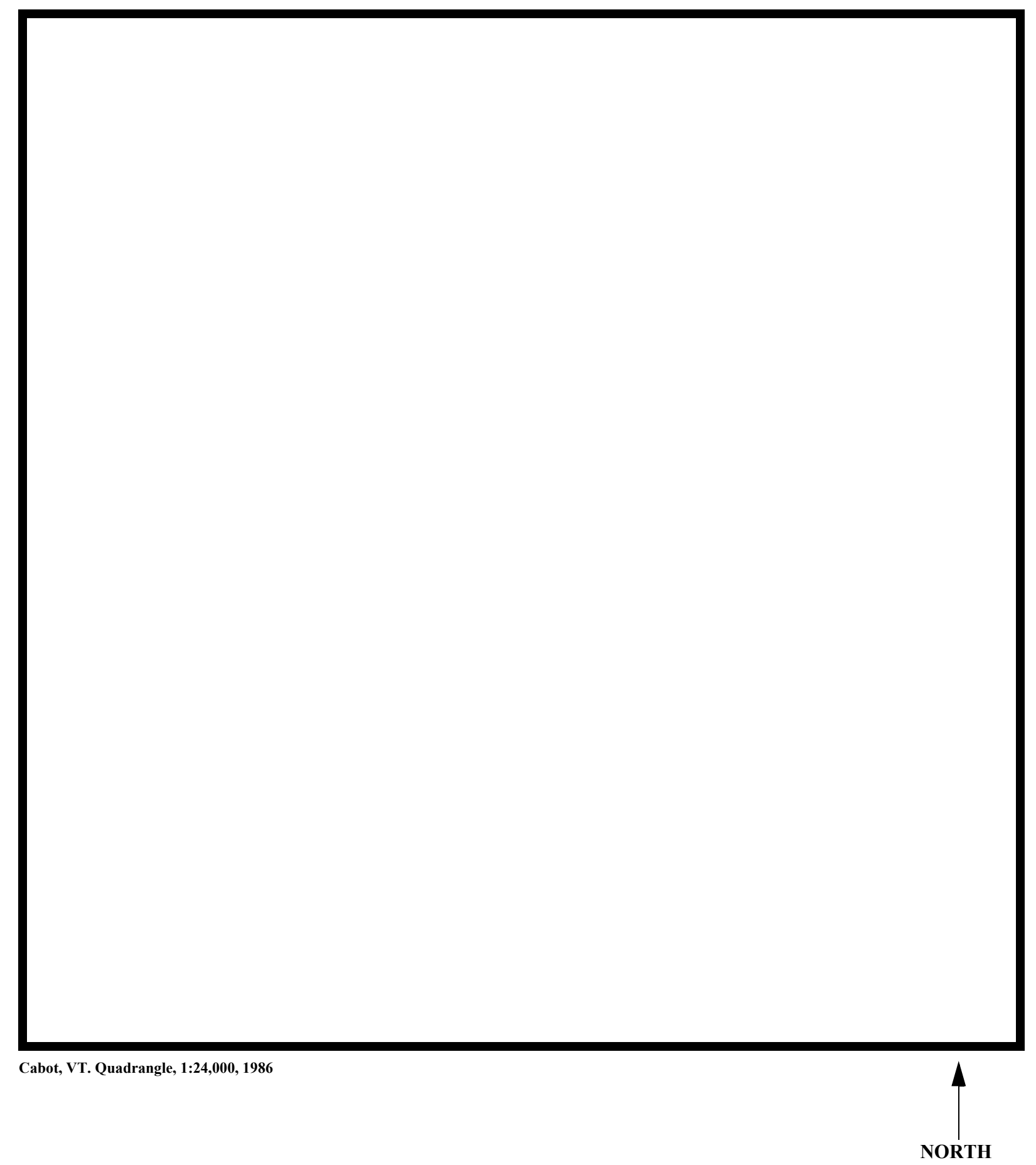

Figure 1. Location of study area on USGS 1:24,000 scale map. 
Figure 2. Location of study area on Vermont Agency of Transportation town highway map. 

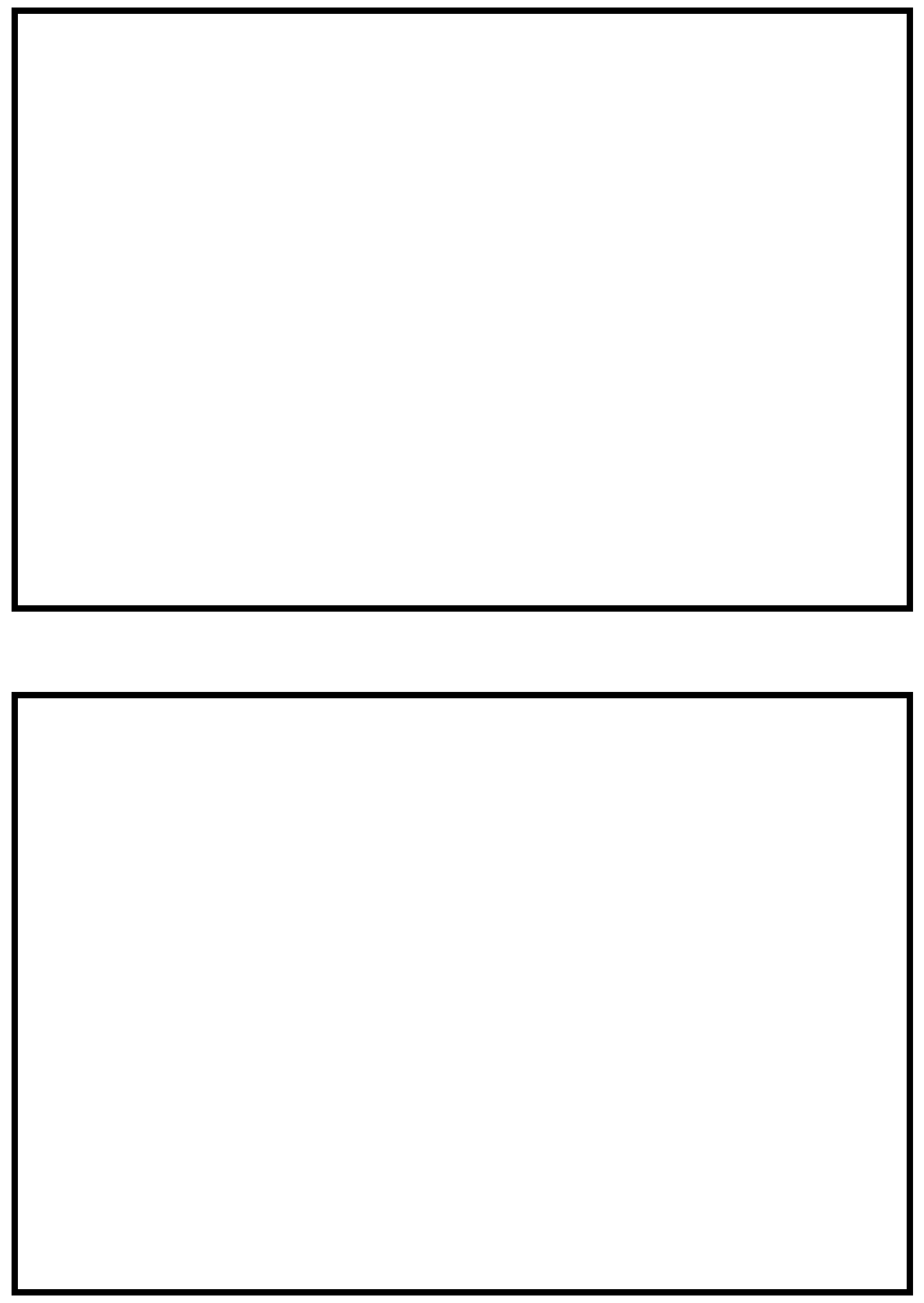

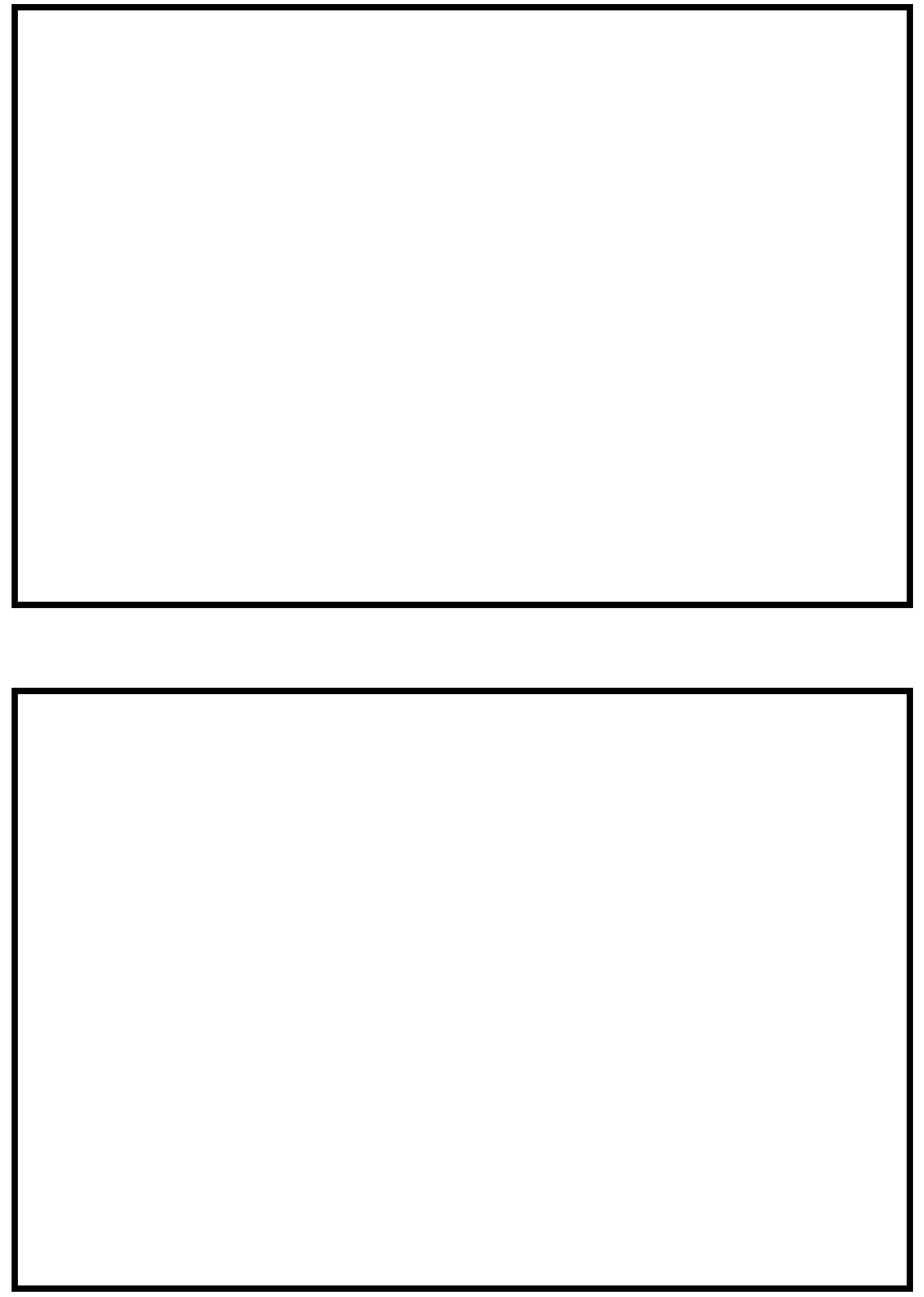


\section{LEVEL II SUMMARY}

\begin{tabular}{llllll} 
Structure Number & \multicolumn{2}{c}{ CABOTH00410037 } & Stream & \multicolumn{2}{l}{ Winooski River } \\
& Wounty & Washington & TH41 & District & 6
\end{tabular}

\section{Description of Bridge}

Bridge length $\stackrel{29}{2} \boldsymbol{f t} \quad$ Bridge width $\frac{16.0}{f t}$ Max span length $\stackrel{26}{ } \boldsymbol{f t}$ Alignment of bridge to road (on curve or straight) "Laid up" Granite Blocks

Abutment type

Stone fill on abutment?

nomouintinw af otow a fill Yes

\section{Embankment type}

Curve, right ; straight, left

Sloping

$7 / 16 / 96$

Dato af incnortion

Type-2, along the entire base length of the left abutment and upstream

are "laid up" granite block. The abutments have concrete footings.

\section{$\mathrm{Y}$} 35

Is bridge skewed to flood flow according to No ' survey? Angle

Debris accumulation on bridge at time of Level I or Level II site visit:

\begin{tabular}{|c|c|c|c|}
\hline & $\begin{array}{c}\text { Date af insnortion } \\
7 / 16 / 96 \\
\end{array}$ & $\begin{array}{l}\text { Percent of alnam an } \\
\text { blocked nortzontatly }\end{array}$ & $\begin{array}{l}\text { Percent of } 0 \\
\text { blocked verticatty }\end{array}$ \\
\hline & $7 / 16 / 96$ & 0 & 0 \\
\hline
\end{tabular}

Level II

Low. Upstream channel banks are lined primarily with brush with

few trees and the channel is laterally stable.

Potential for debris

A dam and waterfall are located approximately 250 feet upstream. Noted on 7/16/96.

Dosriho anv, foaturos noar ar at tho hridos that mav affoct flow, (includo ahsorvation dato) 


\section{Description of the Geomorphic Setting}

General topography The channel is located within a narrow, slightly irregular flood plain within a moderate relief valley setting.

Geomorphic conditions at bridge site: downstream (DS), upstream (US)

Date of inspection $\quad 7 / 16 / 96$

DS left: $\quad$ Steep channel bank to floodplain.

DS right: $\quad$ Moderately sloped channel bank to a moderately sloped overbank.

US left: $\quad$ Moderately sloped channel bank to flood plain.

US right: Steep channel bank to a narrow terrace.

\section{Description of the Channel}

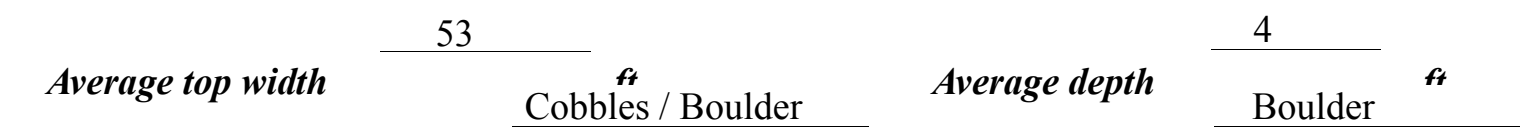

Predominant bed material

Bank material Straight and stable

with non-alluvial channel boundaries and a narrow flood plain.

$7 / 16 / 96$

Vegetative co 1 Trees and brush.

DS left: $\quad$ Trees, shrubs and brush

DS right: $\quad$ Trees and brush.

US left: $\quad$ Short grass and brush with a few trees.

US right: $\quad \underline{\mathrm{Y}}$

Do banks appear stable? -

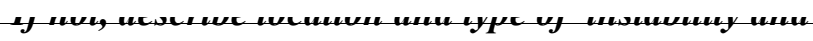

date of observatton.

The assessment of

7/16/96 noted flow conditions are influenced by a small island, approximately $200 \mathrm{ft}$ upstream Describe any obstructions in channel and date of observation.

in the center of the channel and a dam which is approximately $250 \mathrm{ft}$ upstream. 


\title{
Hydrology
}

Drainage area $\stackrel{21.4}{\longrightarrow} \mathbf{m i}^{2}$

Percentage of drainage area in physiographic provinces: (approximate)

Physiographic province/section New England/New England Upland
Percent of drainage area 100

\begin{abstract}
Is drainage area considered rural or urban? Rural Describe any significant urbanization:
\end{abstract}

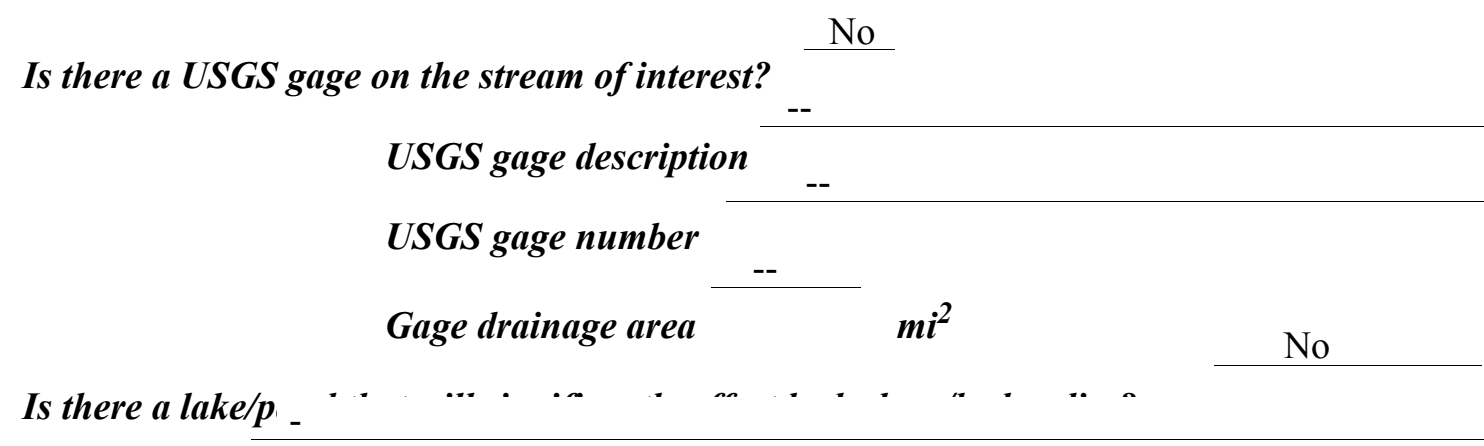

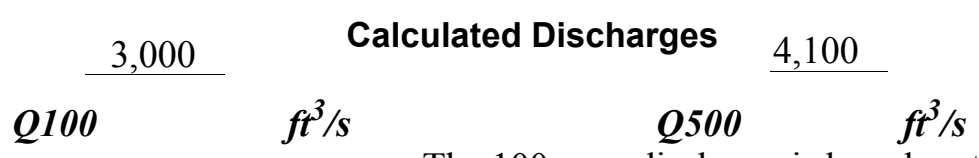

The 100-year discharge is based on the FHWA

discharge frequency curve value which was selected due to its' central tendency with others which were developed from empirical relationships and extended to the 500-year discharge (Benson, 1962; Johnson and Tasker, 1974; FHWA, 1983; Potter, 1957a\&b; Talbot, 1887). 


\section{Description of the Water-Surface Profile Model (WSPRO) Analysis}

Datum for WSPRO analysis (USGS survey, sea level, VTAOT plans)

USGS survey

Datum tie between USGS survey and VTAOT plans

None

Description of reference marks used to determine USGS datum. $\quad$ RM1 is a chiseled X on

top of the downstream end of the right abutment (elev. $499.76 \mathrm{ft}$, arbitrary survey datum). RM2

is a nail in a telephone pole (GMP Corp 3/30 and CTC VT 61-35), two ft above the ground, on

the upstream left road approach, $30 \mathrm{ft}$ bankward of the left abutment (elev. 507.27ft, arbitrary

survey datum).

\section{Cross-Sections Used in WSPRO Analysis}

\begin{tabular}{cccl}
\hline${ }^{1}$ Cross-section & $\begin{array}{c}\text { Section } \\
\text { Reference } \\
\text { Distance } \\
\text { (SRD) } \text { in feet }\end{array}$ & $\begin{array}{c}{ }^{2} \text { Cross-section } \\
\text { development }\end{array}$ & \multicolumn{1}{c}{ Comments } \\
\hline EXITX & -25 & 1 & $\begin{array}{l}\text { Exit section } \\
\text { Downstream Full-valley } \\
\text { section (Templated from } \\
\text { EXITX) }\end{array}$ \\
FULLV & 0 & 2 & $\begin{array}{l}\text { Bridge section } \\
\text { Road Grade section }\end{array}$ \\
RDWHY & 0 & 1 & $\begin{array}{l}\text { Modelled Approach sec- } \\
\text { tion (Templated from } \\
\text { APTEM) }\end{array}$ \\
APPRO & 11 & 1 & $\begin{array}{l}\text { Approach section as sur- } \\
\text { veyed (Used as a tem- } \\
\text { plate) }\end{array}$ \\
\hline
\end{tabular}

${ }^{1}$ For location of cross-sections see plan-view sketch included with Level I field form, Appendix E.

For more detail on how cross-sections were developed see WSPRO input file. 


\section{Data and Assumptions Used in WSPRO Model}

Hydraulic analyses of the reach were done by use of the Federal Highway Administration's WSPRO step-backwater computer program (Shearman and others, 1986, and Shearman, 1990). The analyses reported herein reflect conditions existing at the site at the time of the study. Furthermore, in the development of the model it was necessary to assume no accumulation of debris or ice at the site. Results of the hydraulic model are presented in the Bridge Hydraulic Summary, Appendix B, and figure 7.

Channel roughness factors (Manning's “ $n$ ”) used in the hydraulic model were estimated using field inspections at each cross section following the general guidelines described by Arcement and Schneider (1989). Final adjustments to the values were made during the modelling of the reach. Channel " $\mathrm{n}$ " values for the reach ranged from 0.050 to 0.075 , and overbank " $\mathrm{n}$ " values ranged from 0.060 to 0.120 .

Normal depth at the exit section (EXITX) was assumed as the starting water surface. This depth was computed by use of the slope-conveyance method outlined in the user's manual for WSPRO (Shearman, 1990). The slope used was $0.0104 \mathrm{ft} / \mathrm{ft}$, which was estimated from the topographic map (U.S. Geological Survey, 1986).

The surveyed approach section (APTEM) was moved along the approach channel slope $(0.0303 \mathrm{ft} / \mathrm{ft})$ to establish the modelled approach section (APPRO), one bridge length upstream of the upstream face as recommended by Shearman and others (1986). This location also provides a consistent method for determining scour variables. 


\section{Bridge Hydraulics Summary}

\begin{tabular}{lll} 
Average bridge embankment elevation & 500.3 \\
\cline { 3 - 3 } Average low steel elevation & 498.8 & $\boldsymbol{f t}$
\end{tabular}

100-year discharge $\quad 3,000 \quad \mathrm{ft}^{3} / \mathrm{s}$

Water-surface elevation in bridge opening $\quad 498.9 \quad f t$

Road overtopping? ___ Y Discharge over road __ 541 $\mathrm{ft}^{3} / \mathrm{s}$

\begin{tabular}{lll} 
Area of flow in bridge opening & $270 \quad \mathrm{ft}^{2}$ \\
\cline { 2 - 3 } Average velocity in bridge opening & 9.1 & $\mathrm{ft} / \mathrm{s}$
\end{tabular}

Maximum WSPRO tube velocity at bridge $11.4 \mathrm{ft} / \mathrm{s}$

Water-surface elevation at Approach section with bridge 500.6

Water-surface elevation at Approach section without bridge $\quad 497.5$

Amount of backwater caused by bridge

$3.1 \quad i$

500-year discharge $\quad 4,100 \quad \boldsymbol{f t}^{3} / \mathrm{s}$

Water-surface elevation in bridge opening

$498.9 \boldsymbol{f t}$

$\begin{array}{llll}\text { Road overtopping? ___ Y Discharge over road __ } 1,361 & \mathrm{ft}^{3} / \mathrm{s}\end{array}$

Area of flow in bridge opening $\quad 270 \quad \mathrm{ft}^{2}$

Average velocity in bridge opening $10.1 \mathrm{ft} / \mathrm{s}$

Maximum WSPRO tube velocity at bridge 12.7 's

Water-surface elevation at Approach section with bridge 501.3

Water-surface elevation at Approach section without bridge $\quad 498.6$

Amount of backwater caused by bridge $\quad 2.7$.t

Incipient overtopping discharge $\quad 2,430 \quad \mathrm{ft}^{3} / \mathrm{s}$

Water-surface elevation in bridge opening $\quad 494.7 \quad$ t

Area of flow in bridge opening $\quad 169 \quad \mathrm{ft}^{2}$

Average velocity in bridge opening $\quad 14.4 \quad \mathrm{ft} / \mathrm{s}$

Maximum WSPRO tube velocity at bridge $\quad 18.7 \quad \mathrm{ft} / \mathrm{s}$

Water-surface elevation at Approach section with bridge

Water-surface elevation at Approach section without bridge

Amount of backwater caused by bridge $\quad$\begin{tabular}{ll} 
_t \\
\hline
\end{tabular}

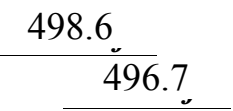




\section{Scour Analysis Summary}

\section{Special Conditions or Assumptions Made in Scour Analysis}

Scour depths were computed using the general guidelines described in Hydraulic Engineering Circular 18 (Richardson and others, 1995). Scour depths were calculated assuming an infinite depth of erosive material and a homogeneous particle-size distribution. The results of the scour analysis are presented in tables 1 and 2 and a graph of the scour depths is presented in figure 8 .

Contraction scour for the incipient roadway-overtopping and maximum free-surface flow through the bridge (with road overflow) discharges was computed by use of the Laursen clear-water contraction scour equation (Richardson and others, 1995, p. 32, equation 20). At this site, the 100- and 500-year discharges resulted in unsubmerged orifice flow. Contraction scour at bridges with orifice flow is best estimated by use of the Chang pressure-flow scour equation (oral communication, J. Sterling Jones, October 4, 1996). Thus, contraction scour for these discharges was computed by use of the Chang equation (Richardson and others, 1995, p. 145-146). The computed streambed armoring depths suggest that armoring will not limit the depth of contraction scour.

For comparison, contraction scour for the discharges resulting in orifice flow was computed by the Umbrell pressure-flow equation (Richardson and others, 1995, p. 144) and the Laursen clear-water contraction scour equation and presented in Appendix F. Furthermore, for those discharges resulting in unsubmerged orifice flow, contraction scour was computed by substituting estimates for the depth of flow at the downstream bridge face in the contraction scour equations. Results with respect to these substitutions are provided in Appendix F.

Abutment scour for the left abutment was computed by use of the Froehlich equation (Richardson and others, 1995, p. 48, equation 28). Variables for the Froehlich equation include the Froude number of the flow approaching the embankments, the length of the embankment blocking flow, and the depth of flow approaching the embankment less any roadway overtopping.

Scour at the right abutment was computed by use of the HIRE equation (Richardson and others, 1995, p. 49, equation 29) because the HIRE equation is recommended when the length to depth ratio of the embankment blocking flow exceeds 25 . The variables used by the HIRE abutment-scour equation are defined the same as those defined for the Froehlich abutment-scour equation. 


\section{Scour Results}

Contraction scour:

Main channel

Live-bed scour

Clear-water scour

Depth to armoring

Left overbank

Right overbank

Local scour:

Abutment scour

Left abutment

Right abutment

Pier scour

Pier 1

Pier 2

Pier 3

\begin{abstract}
Maximum
Free-Surface

100-yrdischarge 500-yrdischarge discharge

(Scour depths in feet)
\end{abstract}

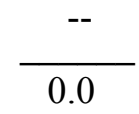

$9.48 .3^{-}$

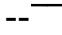

9.815 .2

16.3

13.2
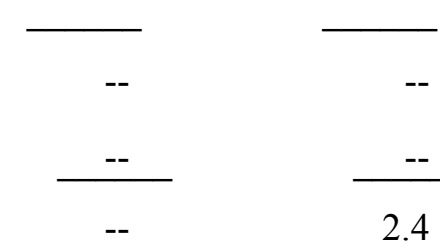

2.4

2.4

\section{Riprap Sizing}

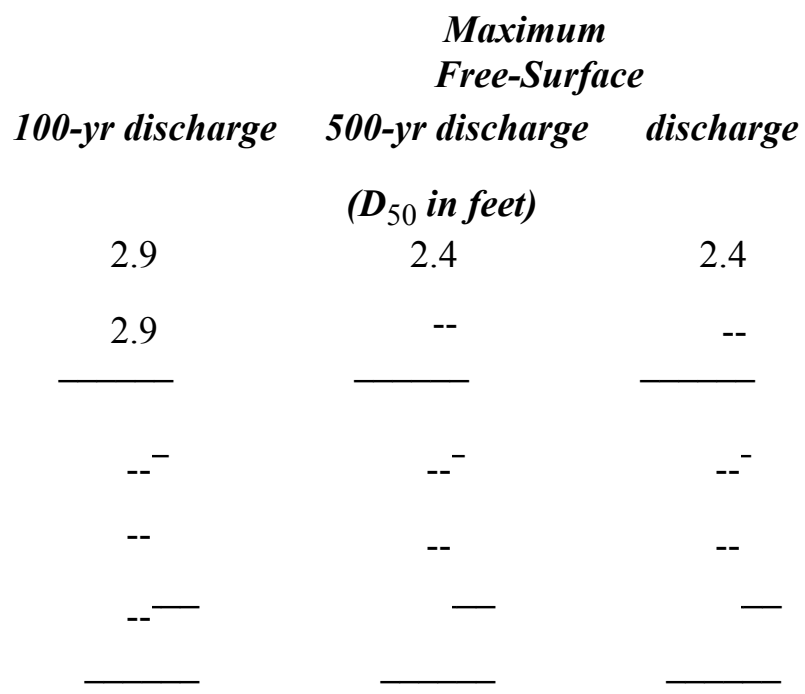




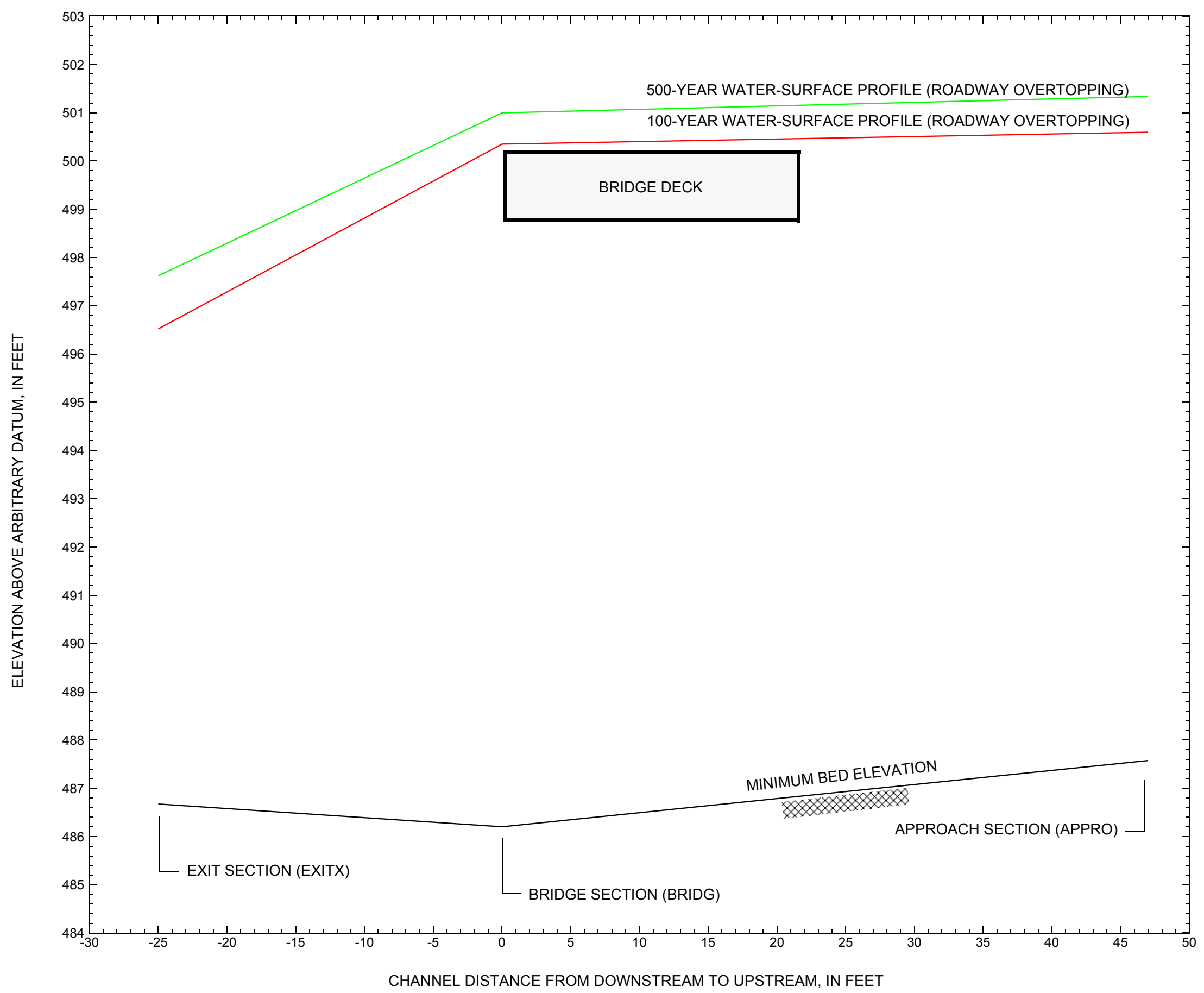

Figure 7. Water-surface profiles for the 100- and 500-year discharges at structure CABOTH00410037 on Town Highway 41, crossing the Winooski River, Cabot, Vermont. 


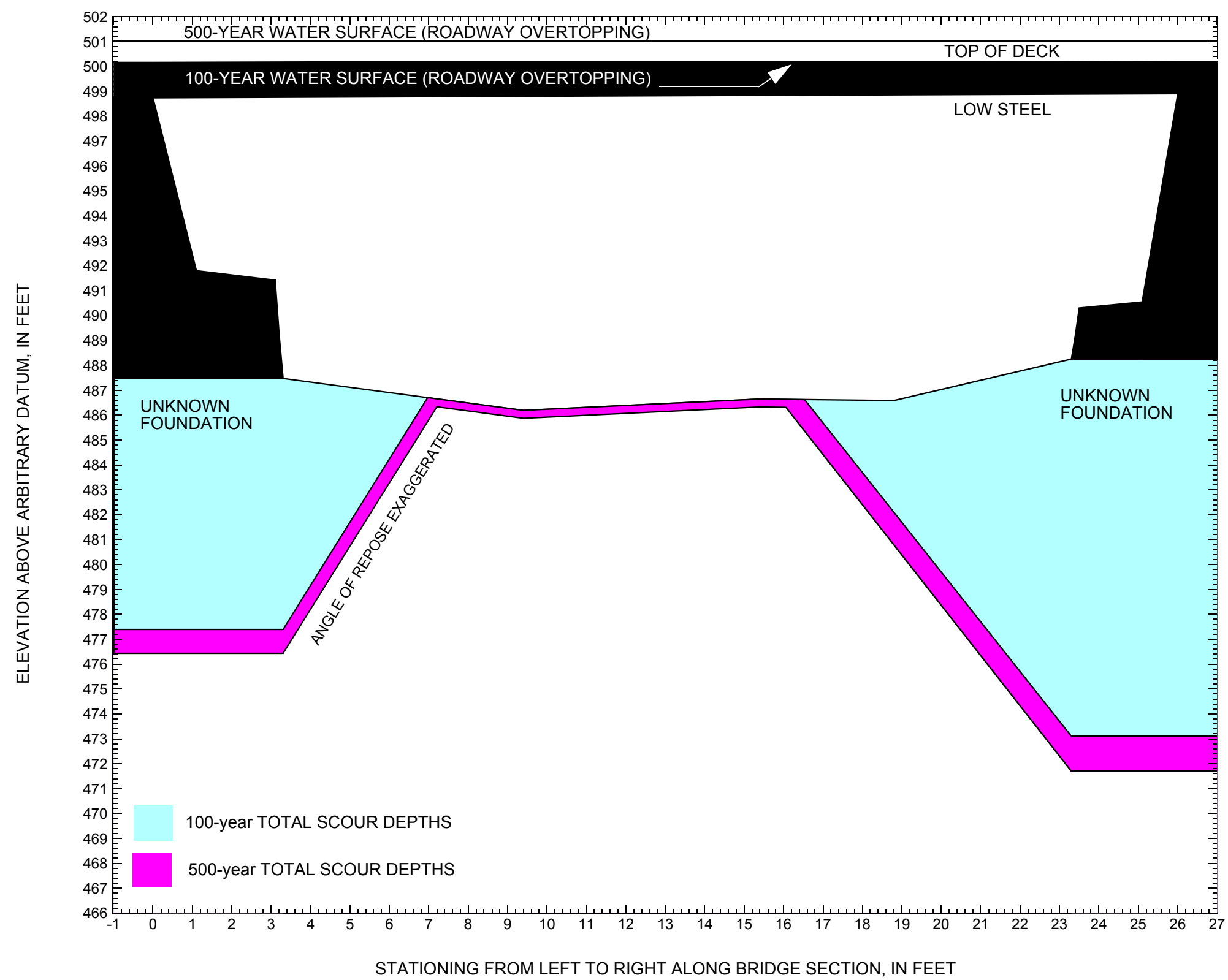

Figure 8. Scour elevations for the 100-year and 500-year discharges at structure CABOTH00410037 on Town Highway 41, crossing the Winooski River, Cabot, Vermont. 
Table 1. Remaining footing/pile depth at abutments for the 100-year discharge at structure CABOTH00410037 on Town Highway 41, crossing the Winooski River, Cabot, Vermont.

[VTAOT, Vermont Agency of Transportation; --,no data]

\begin{tabular}{|c|c|c|c|c|c|c|c|c|c|c|c|}
\hline Description & Station $^{1}$ & $\begin{array}{l}\text { VTAOT } \\
\text { minimum } \\
\text { low-chord } \\
\text { elevation } \\
\text { (feet) }\end{array}$ & $\begin{array}{l}\text { Surveyed } \\
\text { minimum } \\
\text { low-chord } \\
\text { elevation } \\
\text { (feet) }\end{array}$ & $\begin{array}{c}\text { Bottom of } \\
\text { footing/pile } \\
\text { elevation }{ }^{2} \\
\text { (feet) }\end{array}$ & $\begin{array}{c}\text { Channel } \\
\text { elevation at } \\
\text { abutment/ } \\
\text { pier }^{2} \\
\text { (feet) }\end{array}$ & $\begin{array}{l}\text { Contraction } \\
\text { scour depth } \\
\text { (feet) }\end{array}$ & $\begin{array}{l}\text { Abutment } \\
\text { scour } \\
\text { depth } \\
\text { (feet) }\end{array}$ & $\begin{array}{l}\text { Pier } \\
\text { scour } \\
\text { depth } \\
\text { (feet) }\end{array}$ & $\begin{array}{l}\text { Depth of } \\
\text { total scour } \\
\text { (feet) }\end{array}$ & $\begin{array}{c}\text { Elevation of } \\
\text { scour }^{2} \\
\text { (feet) }\end{array}$ & $\begin{array}{c}\text { Remaining } \\
\text { footing/pile } \\
\text { depth } \\
\text { (feet) }\end{array}$ \\
\hline \multicolumn{12}{|c|}{100 -year. discharge is 3,000 cubic-feet per second } \\
\hline Left abutment & 0.0 & - & 498.8 & - & 487.5 & 0.0 & 10.1 & -- & 10.1 & 477.4 & - \\
\hline Right abutment & 26.0 & - & 498.9 & - & 488.3 & 0.0 & 15.2 & -- & 15.2 & 473.1 & - \\
\hline
\end{tabular}

1.Measured along the face of the most constricting side of the bridge.

2.Arbitrary datum for this study.

Table 2. Remaining footing/pile depth at abutments for the 500-year discharge at structure CABOTH00410037 on Town Highway 41, crossing the Winooski River, Cabot, Vermont.

[VTAOT, Vermont Agency of Transportation; --, no data]

\begin{tabular}{|c|c|c|c|c|c|c|c|c|c|c|c|}
\hline Description & Station $^{1}$ & $\begin{array}{l}\text { VTAOT } \\
\text { minimum } \\
\text { low-chord } \\
\text { elevation } \\
\text { (feet) }\end{array}$ & $\begin{array}{c}\text { Surveyed } \\
\text { minimum } \\
\text { low-chord } \\
\text { elevation } \\
\text { (feet) }\end{array}$ & $\begin{array}{c}\text { Bottom of } \\
\text { footing/pile } \\
\text { elevation } \\
\text { (feet) }\end{array}$ & $\begin{array}{c}\text { Channel } \\
\text { elevation at } \\
\text { abutment/ } \\
\text { pier }^{2} \\
\text { (feet) }\end{array}$ & $\begin{array}{l}\text { Contraction } \\
\text { scour depth } \\
\text { (feet) }\end{array}$ & $\begin{array}{c}\text { Abutment } \\
\text { scour } \\
\text { depth } \\
\text { (feet) }\end{array}$ & $\begin{array}{l}\text { Pier } \\
\text { scour } \\
\text { depth } \\
\text { (feet) }\end{array}$ & $\begin{array}{l}\text { Depth of } \\
\text { total scour } \\
\text { (feet) }\end{array}$ & $\begin{array}{c}\text { Elevation of } \\
\text { scour }^{2} \\
\text { (feet) }\end{array}$ & $\begin{array}{c}\text { Remaining } \\
\text { footing/pile } \\
\text { depth } \\
\text { (feet) }\end{array}$ \\
\hline \multicolumn{12}{|c|}{500 -year. discharge is 4,100 cubic-feet per second } \\
\hline Left abutment & 0.0 & - & 498.8 & - & 487.5 & 0.3 & 10.7 & -- & 11.0 & 476.5 & - \\
\hline Right abutment & 26.0 & - & 498.9 & - & 488.3 & 0.3 & 16.3 & -- & 16.6 & 471.7 & - \\
\hline
\end{tabular}

1.Measured along the face of the most constricting side of the bridge.

2.Arbitrary datum for this study. 


\section{SELECTED REFERENCES}

Arcement, G.J., Jr., and Schneider, V.R., 1989, Guide for selecting Manning's roughness coefficients for natural channels and flood plains: U.S. Geological Survey Water-Supply Paper 2339, 38 p.

Barnes, H.H., Jr., 1967, Roughness characteristics of natural channels: U.S. Geological Survey Water-Supply Paper 1849,213 p.

Benson, M. A., 1962, Factors Influencing the Occurrence of Floods in a Humid Region of Diverse Terrain: U.S. Geological Survey WaterSupply Paper 1580-B, 64 p.

Brown, S.A. and Clyde, E.S., 1989, Design of riprap revetment: Federal Highway Administration Hydraulic Engineering Circular No. 11, Publication FHWA-IP-89-016, 156 p.

Federal Highway Administration, 1983, Runoff estimates for small watersheds and development of sound design: Federal Highway Administration Report FHWA-RD-77-158.

Federal Highway Administration, 1993, Stream Stability and Scour at Highway Bridges: Participant Workbook: Federal Highway Administration Report FHWA-HI-91-011.

Froehlich, D.C., 1989, Local scour at bridge abutments in Ports, M.A., ed., Hydraulic Engineering--Proceedings of the 1989 National Conference on Hydraulic Engineering: New York, American Society of Civil Engineers, p. 13-18.

Hayes, D.C.,1993, Site selection and collection of bridge-scour data in Delaware, Maryland, and Virginia: U.S. Geological Survey WaterResources Investigation Report 93-4017, 23 p.

Interagency Advisory Committee on Water Data, 1982, Guidelines for determining flood flow frequency: U.S. Geological Survey, Bulletin 17B of the Hydrology Subcommittee, $190 \mathrm{p}$.

Johnson, C.G. and Tasker, G.D.,1974, Progress report on flood magnitude and frequency of Vermont streams: U.S. Geological Survey OpenFile Report 74-130, 37 p.

Lagasse, P.F., Schall, J.D., Johnson, F., Richardson, E.V., Chang, F., 1995, Stream Stability at Highway Structures: Federal Highway Administration Hydraulic Engineering Circular No. 20, Publication FHWA-IP-90-014, 144 p.

Laursen, E.M., 1960, Scour at bridge crossings: Journal of the Hydraulics Division, American Society of Civil Engineers, v. 86, no. HY2, p. 39-53.

Potter, W. D., 1957a, Peak rates of runoff in the Adirondack, White Mountains, and Maine woods area, Bureau of Public Roads

Potter, W. D., 1957b, Peak rates of runoff in the New England Hill and Lowland area, Bureau of Public Roads

Richardson, E.V. and Davis, S.R., 1995, Evaluating scour at bridges: Federal Highway Administration Hydraulic Engineering Circular No. 18, Publication FHWA-IP-90-017, 204 p.

Richardson, E.V., Simons, D.B., and Julien, P.Y., 1990, Highways in the river environment: Federal Highway Administration Publication FHWA-HI-90-016.

Ritter, D.F., 1984, Process Geomorphology: W.C. Brown Co., Debuque, Iowa, 603 p.

Shearman, J.O., 1990, User's manual for WSPRO--a computer model for water surface profile computations: Federal Highway Administration Publication FHWA-IP-89-027, 187 p.

Shearman, J.O., Kirby, W.H., Schneider, V.R., and Flippo, H.N., 1986, Bridge waterways analysis model; research report: Federal Highway Administration Publication FHWA-RD-86-108, 112 p.

Talbot, A.N., 1887, The determination of water-way for bridges and culverts.

U.S. Department of Transportation, 1993, Stream stability and scour at highway bridges, Participant Workbook: Federal Highway Administration Publication FHWA HI-91-011.

U.S. Geological Survey, 1986, Cabot, Vermont 7.5 Minute Series quadrangle map: U.S. Geological Survey Topographic Maps, Scale $1: 24,000$. 


\section{APPENDIX A: \\ WSPRO INPUT FILE}




\section{WSPRO INPUT FILE}

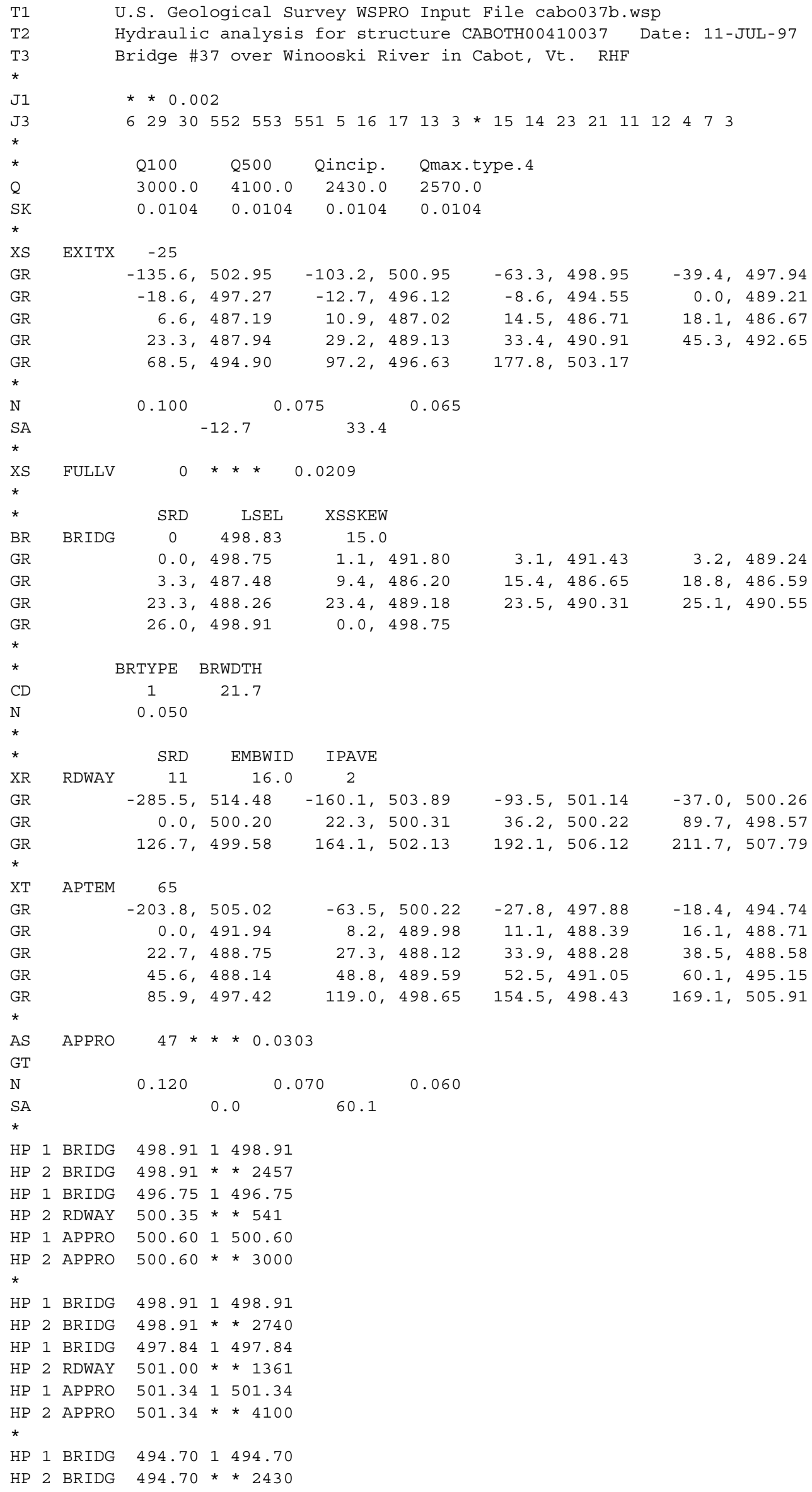




\section{APPENDIX B: \\ WSPRO OUTPUT FILE}




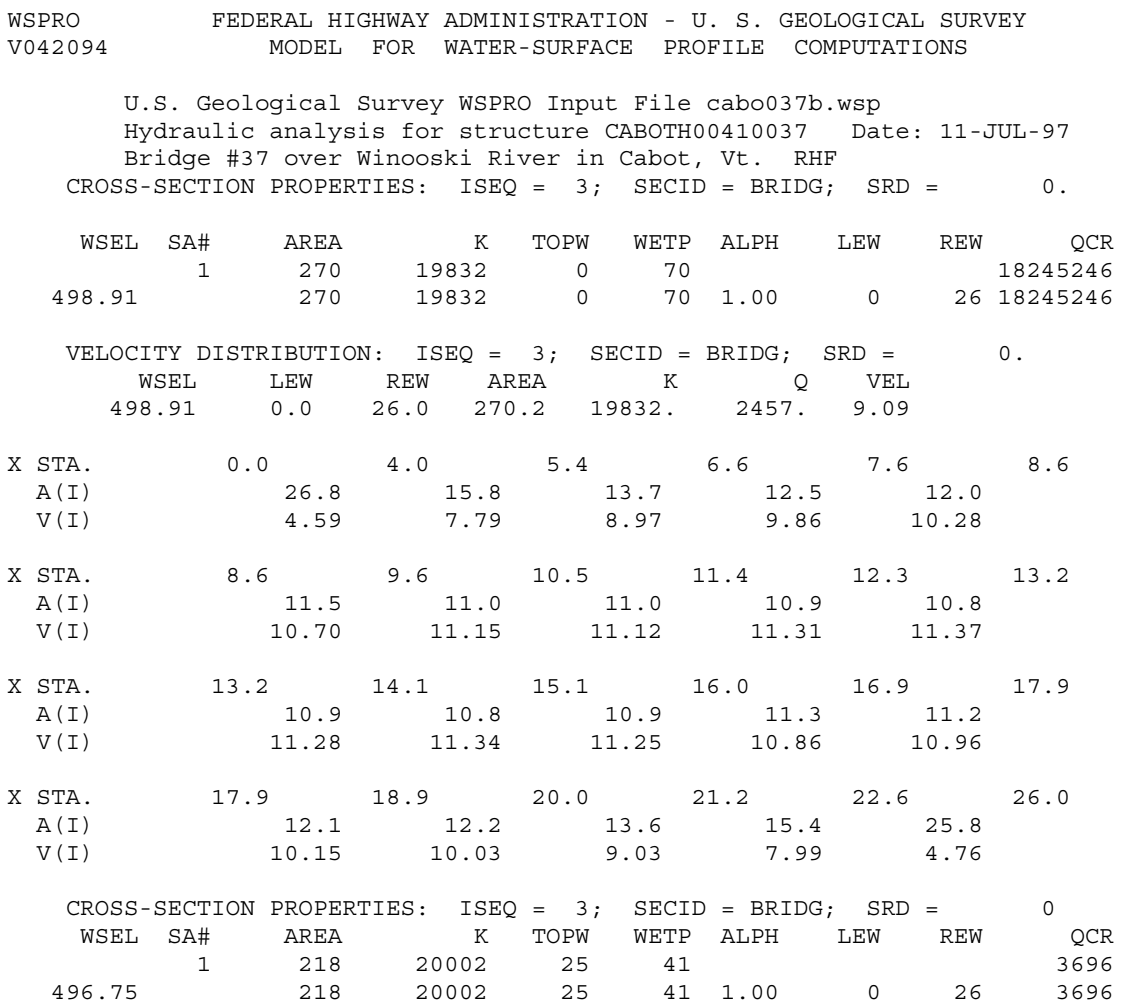

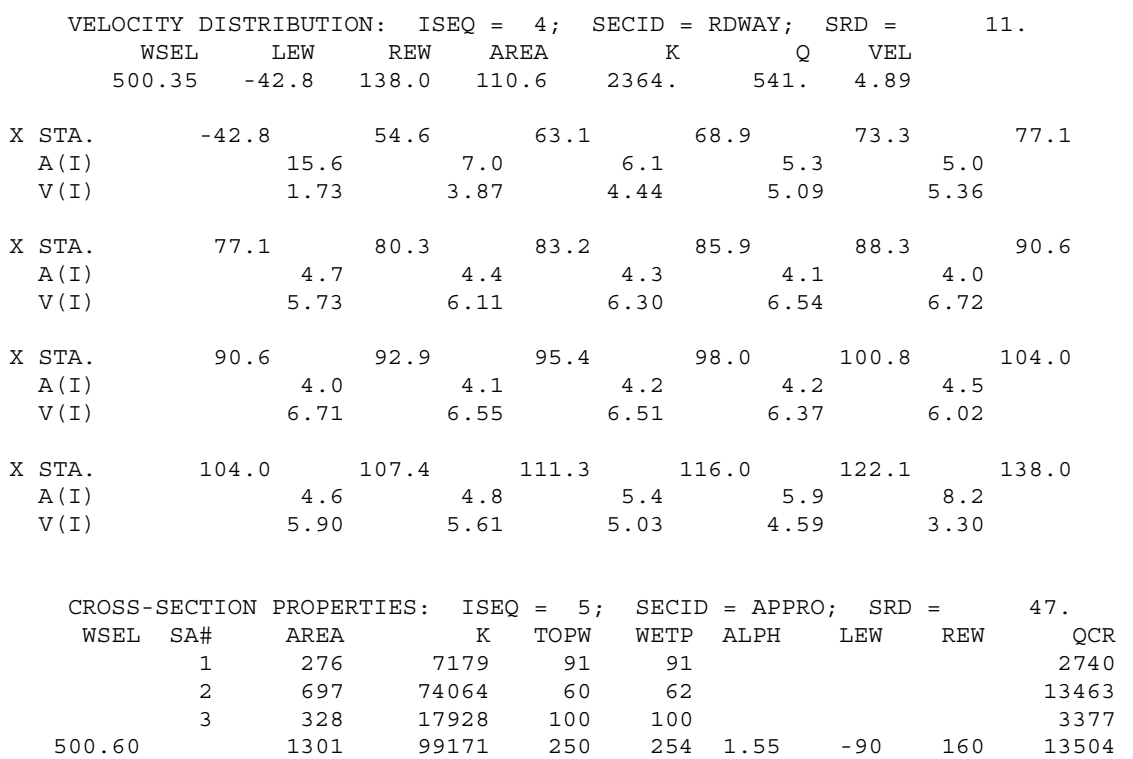

VELOCITY DISTRIBUTION: ISEQ $=5 ; \quad \operatorname{SECID}=\mathrm{APPRO} ; \quad \mathrm{SRD}=47$.

$\begin{array}{rrrrrrr}\text { WSEL } & \text { LEW } & \text { REW } & \text { AREA } & \text { K } & \text { Q } & \text { VEL } \\ 500.60 & -90.5 & 159.8 & 1301.2 & 99171 . & 3000 . & 2.31\end{array}$

\begin{tabular}{|c|c|c|c|c|c|c|c|c|c|c|}
\hline \multirow[t]{3}{*}{$\mathrm{X}$} & STA. & -90.5 & -7.0 & & 3.1 & & 7.8 & & 11.8 & 15.2 \\
\hline & $A(I)$ & 215.3 & & 90.8 & & 49.1 & & 48.3 & & \\
\hline & $V(I)$ & 0.70 & & 1.65 & & 3.05 & & 3.10 & & \\
\hline \multirow[t]{3}{*}{ X } & STA. & 15.2 & 18.7 & & 22.2 & & 25.8 & & 29.0 & 32.3 \\
\hline & $A(I)$ & 43.1 & & 43.5 & & 44.6 & & 42.4 & & \\
\hline & $V(I)$ & 3.48 & & 3.45 & & 3.36 & & 3.54 & & \\
\hline \multirow[t]{3}{*}{$\mathrm{X}$} & STA. & 32.3 & 35.7 & & 39.1 & & 42.6 & & 46.0 & 50.2 \\
\hline & $A(I)$ & 43.9 & & 43.2 & & 43.9 & & 44.3 & & \\
\hline & $V(I)$ & 3.42 & & 3.47 & & 3.41 & & 3.39 & & \\
\hline \multirow[t]{3}{*}{$\mathrm{X}$} & STA. & 50.2 & 56.2 & & 67.9 & & 84.6 & & 114.0 & 159.8 \\
\hline & $A(I)$ & 57.6 & & 71.4 & & 76.7 & & 94.8 & & \\
\hline & $\mathrm{V}(\mathrm{I})$ & 2.60 & & 2.10 & & 1.96 & & 1.58 & & \\
\hline
\end{tabular}




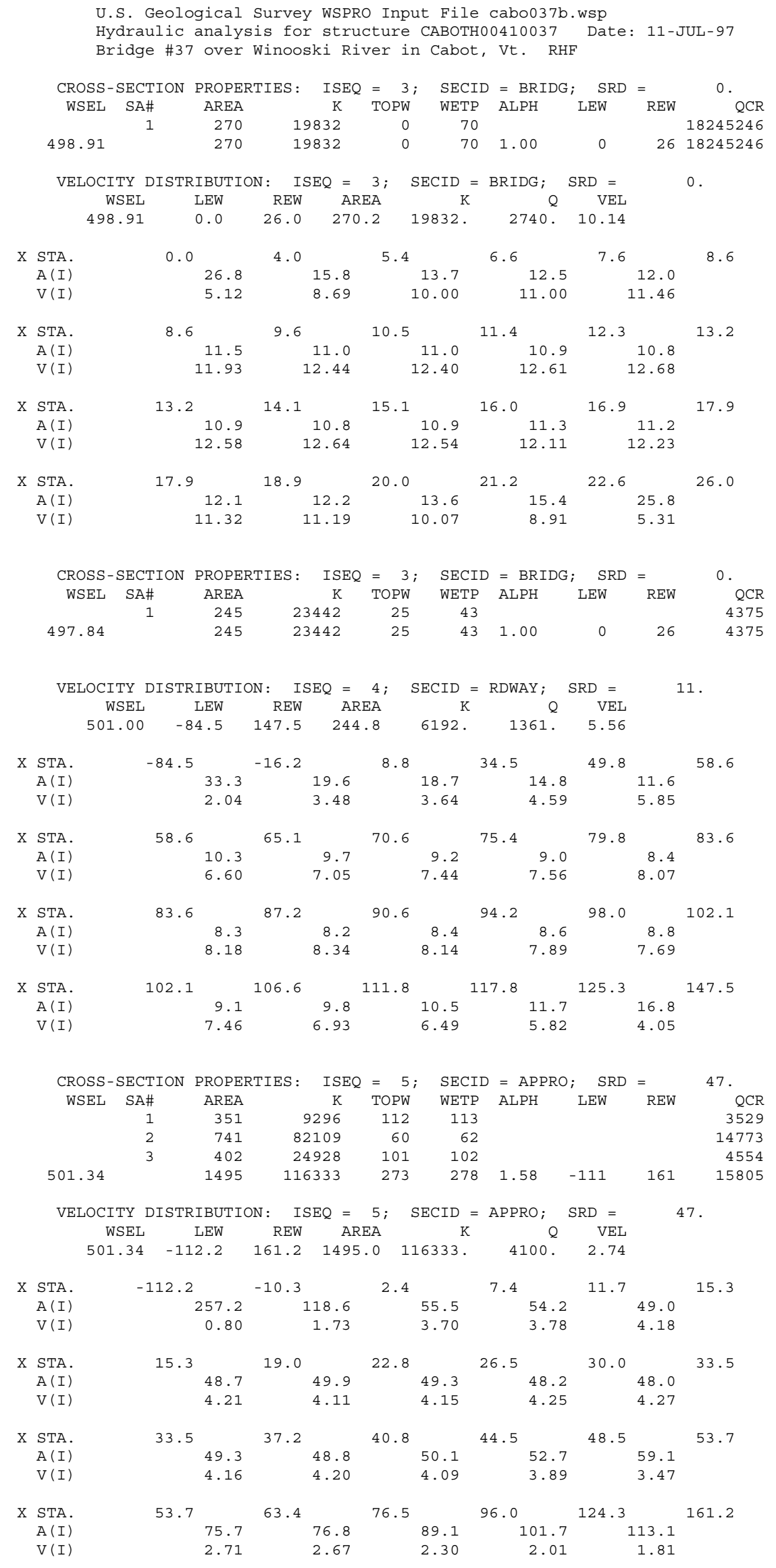


WSPRO OUTPUT FILE (continued)

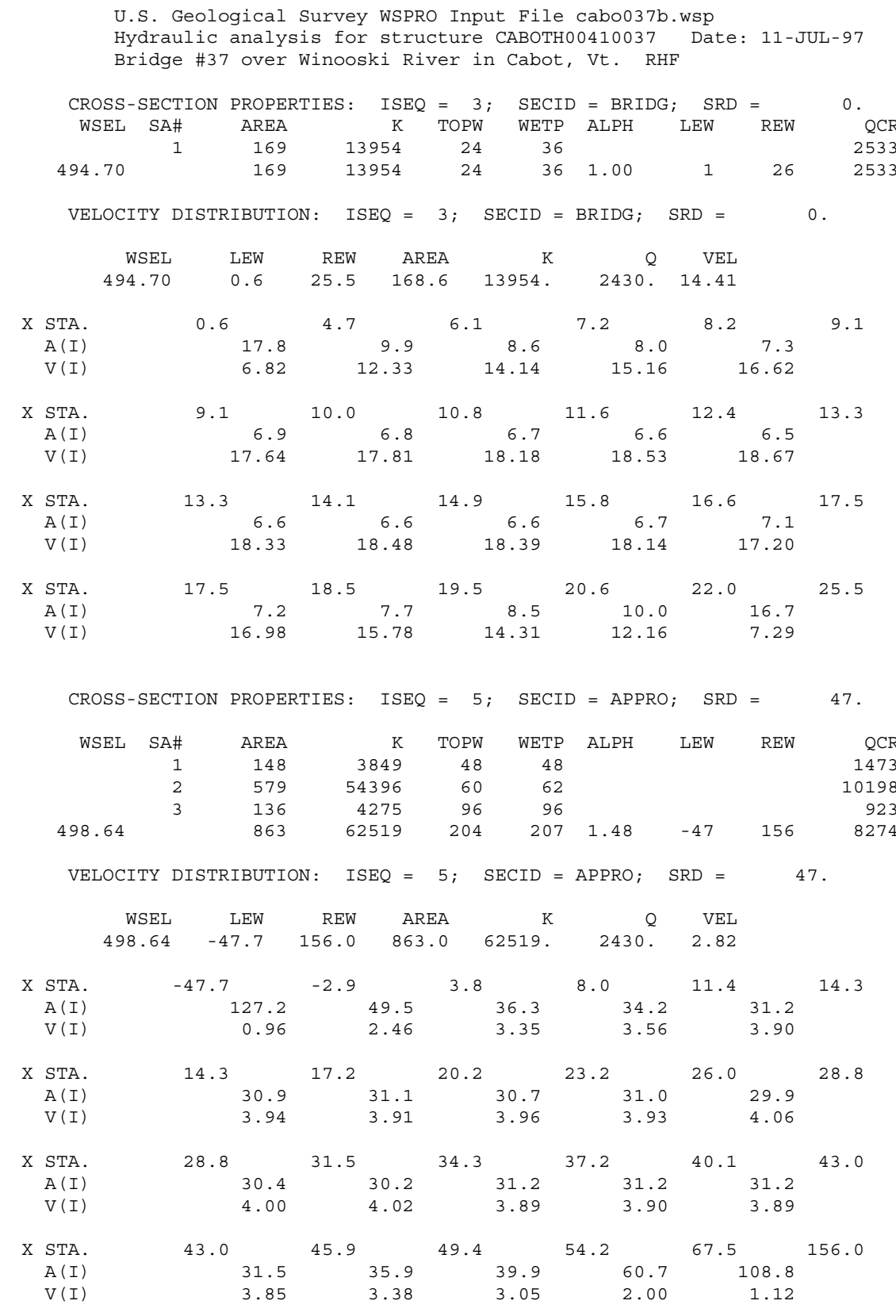


WSPRO OUTPUT FILE (continued)

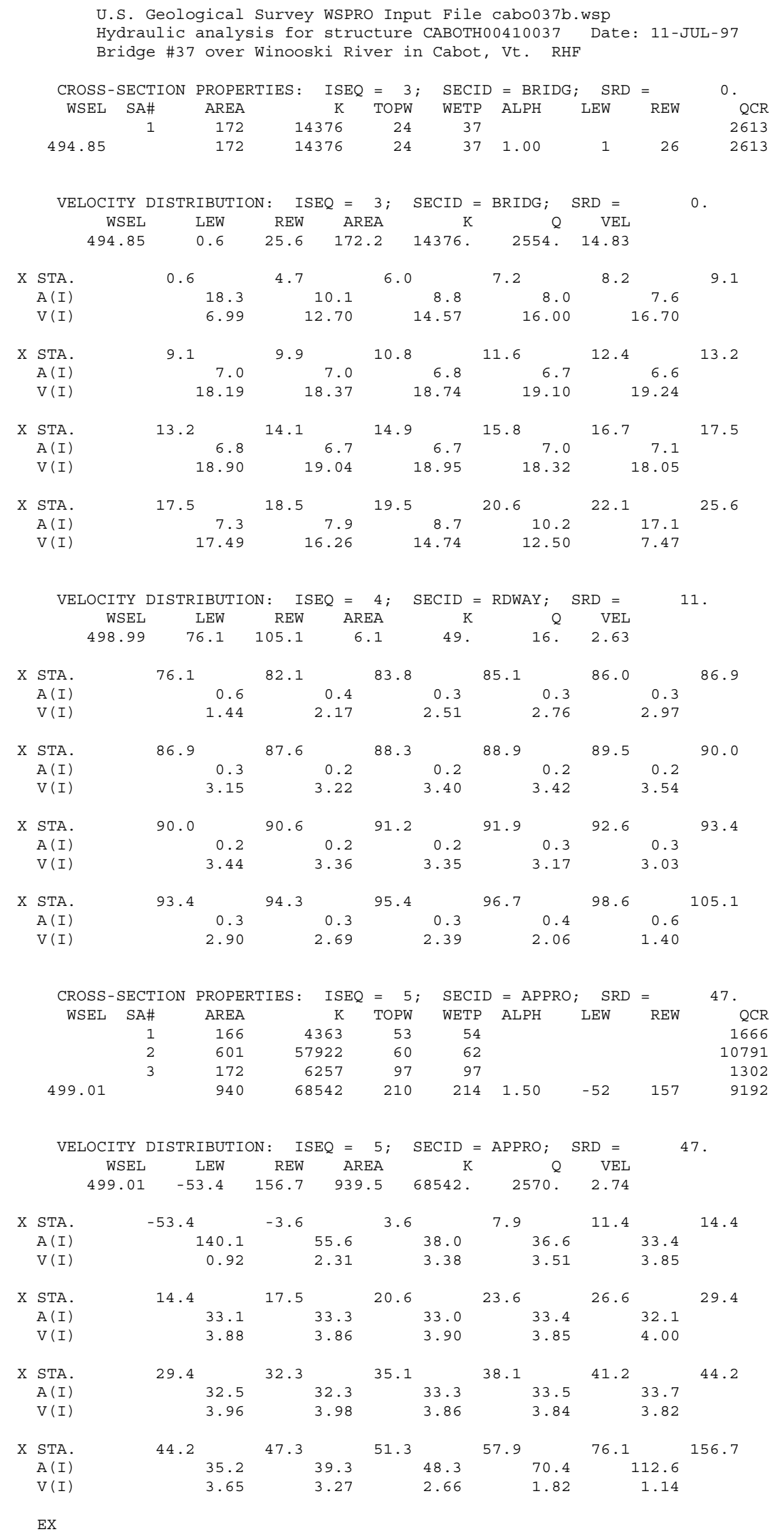


WSPRO OUTPUT FILE (continued)

WSPRO FEDERAL HIGHWAY ADMINISTRATION - U. S. GEOLOGICAL SURVEY

V042094 MODEL FOR WATER-SURFACE PROFILE COMPUTATIONS

U.S. Geological Survey WSPRO Input File cabo037b.wsp

Hydraulic analysis for structure CABOTH00410037 Date: 11-JUL-97

Bridge \#37 over Winooski River in Cabot, Vt. RHF

*** RUN DATE \& TIME: 07-21-97 09:28

\begin{tabular}{|c|c|c|c|c|c|c|c|c|c|}
\hline XSID: CODE & SRDL & LEW & AREA & VHD & $\mathrm{HF}$ & EGL & CRWS & $Q$ & WSEL \\
\hline SRD & FLEN & REW & K & ALPH & HO & ERR & FR\# & VEL & \\
\hline EXITX:XS & $\star \star \star \star * \star *$ & -14 & 475 & 0.72 & 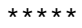 & 497.24 & 494.25 & 3000 & 496.52 \\
\hline-24 & 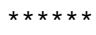 & 95 & 29399 & 1.16 & $\star * * * *$ & 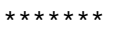 & 0.58 & 6.31 & \\
\hline FULLV : FV & 25 & -12 & 443 & 0.82 & 0.28 & 497.56 & 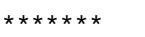 & 3000 & 496.75 \\
\hline 0 & 25 & 91 & 26923 & 1.15 & 0.05 & -0.01 & 0.62 & 6.76 & \\
\hline$<$ & $<<<\mathrm{THE}$ & $\mathrm{VE}$ & JLTS R & FLCT & "NORM & (UNCC & NSTRICTED) & FLOW & $\gg>$ \\
\hline
\end{tabular}

$==135$ CONVEYANCE RATIO OUTSIDE OF RECOMMENDED LIMITS

"APPRO" KRATIO $=1.79$

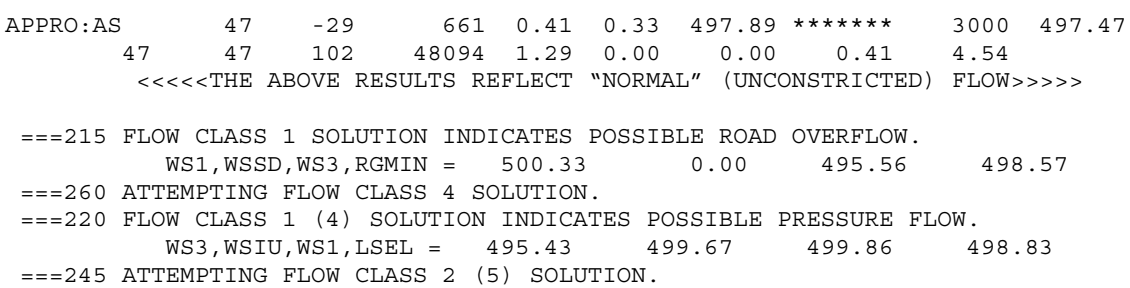

FIRST USER DEFINED TABLE.

$\begin{array}{lrrrrrrrr}\text { XSID : CODE } & \text { SRD } & \text { LEW } & \text { REW } & \text { Q } & \text { K } & \text { AREA } & \text { VEL } & \text { WSEL } \\ \text { EXITX : XS } & -25 . & -15 . & 95 . & 3000 . & 29399 . & 475 . & 6.31 & 496.52 \\ \text { FULLV : FV } & 0 . & -13 . & 91 . & 3000 . & 26923 . & 443 . & 6.76 & 496.75 \\ \text { BRIDG : BR } & 0 . & 0 . & 26 . & 2457 . & 19832 . & 270 . & 9.09 & 498.91 \\ \text { RDWAY : RG } & 11 . * * * * * * * & 47 . & 541 . & 0 . * * * * * * * * & 2.00 & 500.35 \\ \text { APPRO : AS } & 47 . & -91 . & 160 . & 3000 . & 99258 . & 1302 . & 2.30 & 500.60\end{array}$

SECOND USER DEFINED TABLE.

$\begin{array}{lcrrrrrrrr}\text { XSID : CODE } & \text { CRWS } & \text { FR\# } & \text { YMIN } & \text { YMAX } & \text { HF } & \text { HO } & \text { VHD } & \text { EGL } & \text { WSEL } \\ \text { EXITX:XS } & 494.25 & 0.58 & 486.67 & 503.17 * * * * * * * * * * & 0.72 & 497.24 & 496.52 \\ \text { FULLV:FV } & * * * * * * * * & 0.62 & 487.19 & 503.69 & 0.28 & 0.05 & 0.82 & 497.56 & 496.75 \\ \text { BRIDG : BR } & 494.56 & 0.50 & 486.20 & 498.91 * * * * * * * * * * * & 1.29 & 500.20 & 498.91 \\ \text { RDWAY:RG } & * * * * * * * * * * * * * * * & 498.57 & 514.48 & 0.03 * * * * * * & 0.13 & 500.70 & 500.35 \\ \text { APPRO:AS } & 493.23 & 0.22 & 487.57 & 505.36 & 0.11 & 0.68 & 0.13 & 500.73 & 500.60\end{array}$


WSPRO OUTPUT FILE (continued)

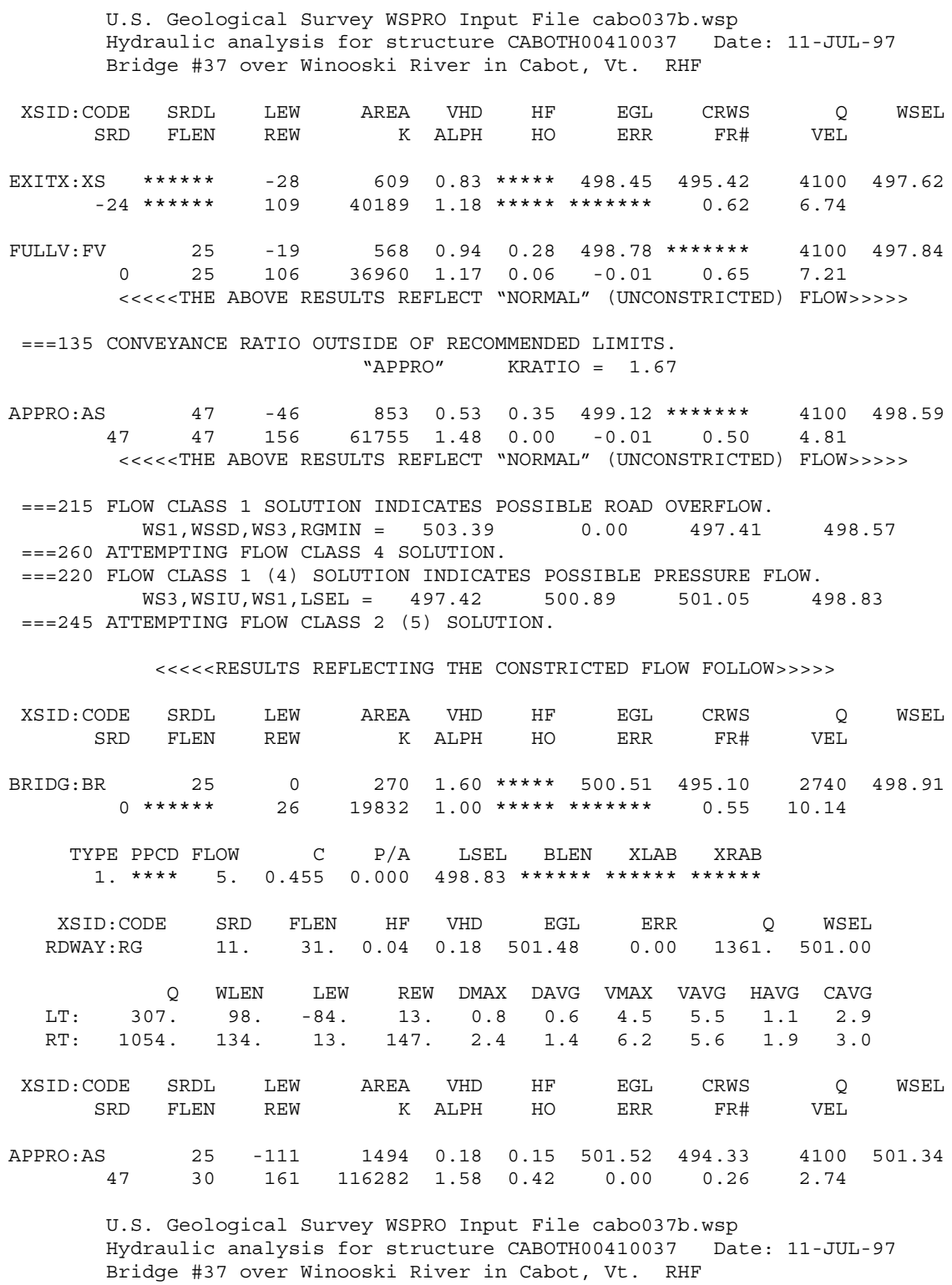

FIRST USER DEFINED TABLE.

\begin{tabular}{|c|c|c|c|c|c|c|c|c|}
\hline XSID : CODE & SRD & LEW & REW & 0 & K & AREA & VEL & WSEL \\
\hline EXITX:XS & -25. & -29 & 109. & 4100. & 40189. & 609. & 6.74 & 497.62 \\
\hline FULLV : FV & 0 . & -20 & 106. & 4100. & 36960. & 568. & 7.21 & 497.84 \\
\hline BRIDG : BR & 0 . & 0 . & 26. & 2740. & 19832. & 270 . & 10.14 & 498.91 \\
\hline DWAY : RG & $11 . *$ & $\star \star \star \star \star *$ & 307. & 1361. & 0 . & $* \star \star \star \star * *$ & 2.00 & 501.00 \\
\hline APPRO:AS & 47. & -112. & 161. & 4100. & 116282 . & 1494. & 2.74 & 501.3 \\
\hline
\end{tabular}

SECOND USER DEFINED TABLE.

$\begin{array}{lcrrrrrrrr}\text { XSID : CODE } & \text { CRWS } & \text { FR\# } & \text { YMIN } & \text { YMAX } & \text { HF } & \text { HO } & \text { VHD } & \text { EGL } & \text { WSEL } \\ \text { EXITX:XS } & 495.42 & 0.62 & 486.67 & 503.17 * * * * * * * * * * & 0.83 & 498.45 & 497.62 \\ \text { FULLV : FV } & * * * * * * * * & 0.65 & 487.19 & 503.69 & 0.28 & 0.06 & 0.94 & 498.78 & 497.84 \\ \text { BRIDG : BR } & 495.10 & 0.55 & 486.20 & 498.91 * * * * * * * * * * & 1.60 & 500.51 & 498.91 \\ \text { RDWAY : RG } & * * * * * * * * * * * * * * * & 498.57 & 514.48 & 0.04 * * * * * * & 0.18 & 501.48 & 501.00 \\ \text { APPRO:AS } & 494.33 & 0.26 & 487.57 & 505.36 & 0.15 & 0.42 & 0.18 & 501.52 & 501.34\end{array}$


WSPRO OUTPUT FILE (continued)

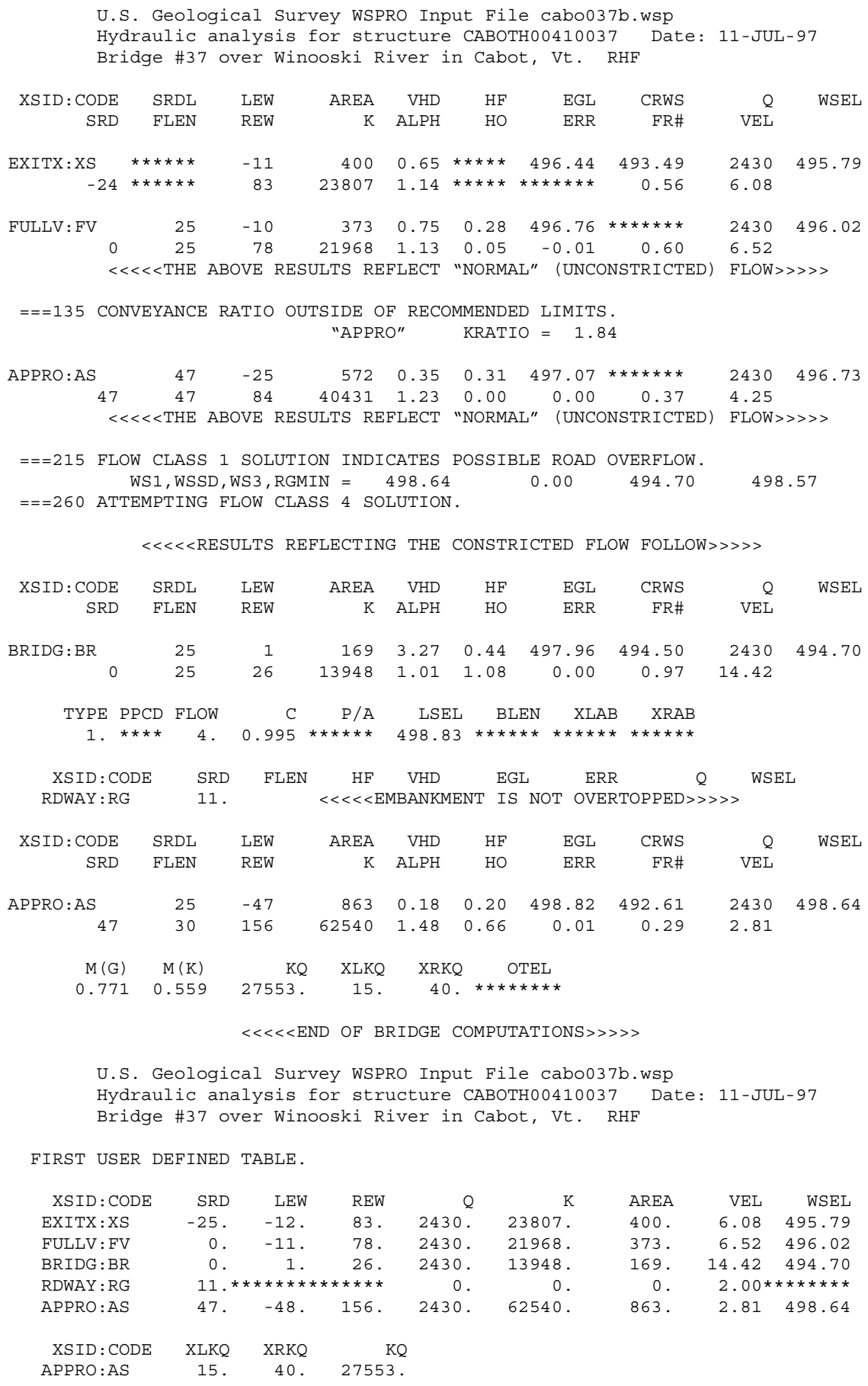


WSPRO OUTPUT FILE (continued)

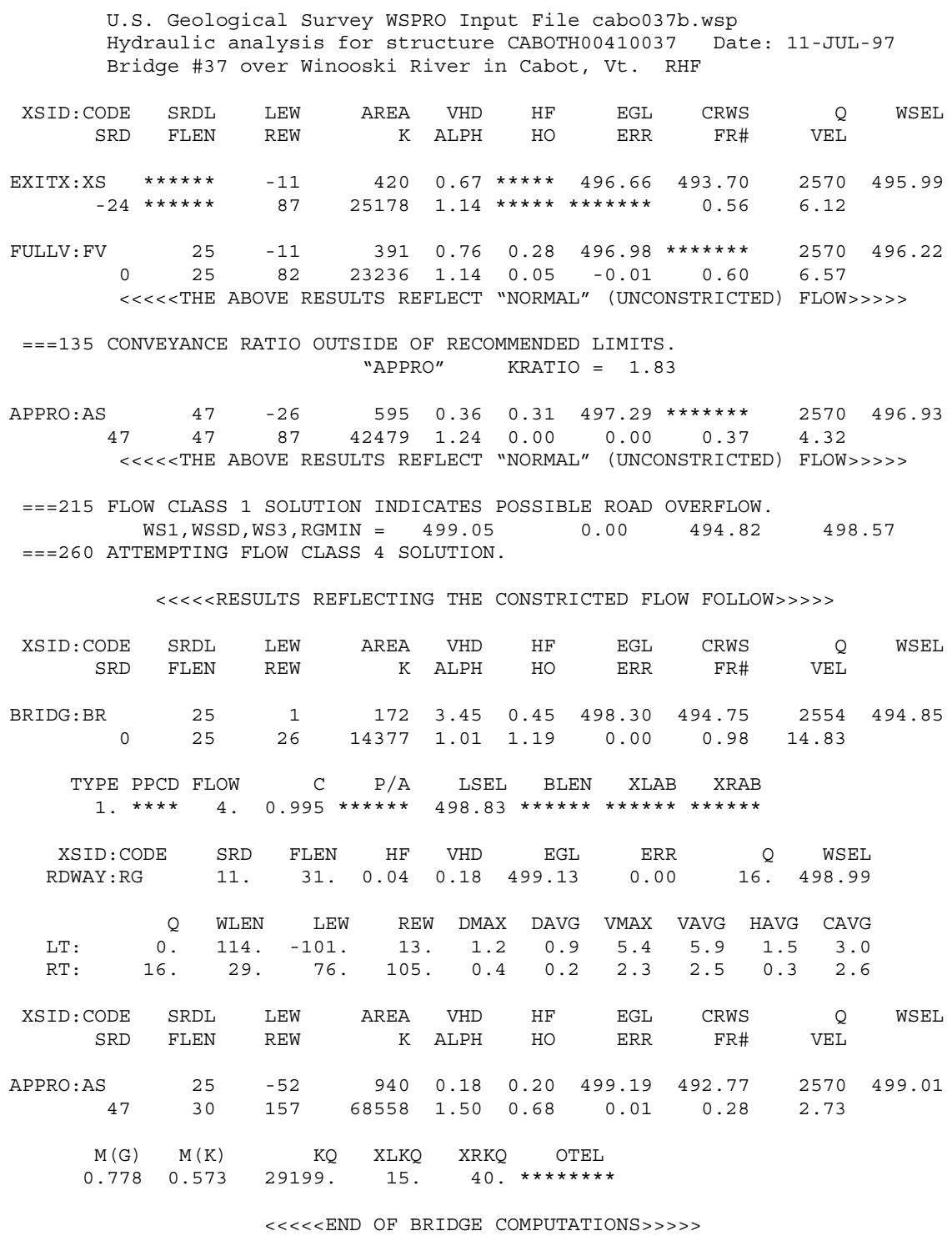

U.S. Geological Survey WSPRO Input File cabo037b.wsp

Hydraulic analysis for structure CABОTH00410037 Date: 11-JUL-97

Bridge \#37 over Winooski River in Cabot, Vt. RHF

FIRST USER DEFINED TABLE.

\begin{tabular}{|c|c|c|c|c|c|c|c|c|}
\hline XSID : CODE & SRD & LEW & REW & $Q$ & K & AREA & VEL & WSEL \\
\hline EXITX:XS & -25 & -12 & 87. & 2570 . & 25178 . & 420 & 6.12 & 495.99 \\
\hline FULLV: FV & 0 . & -12 & 82 . & 2570 . & 23236 . & 391. & 6.57 & 496.22 \\
\hline BRIDG : BR & 0. & 1. & 26 . & 2554 . & 14377 . & 172 . & 14.83 & 494.85 \\
\hline RDWAY : RG & $11 . *$ & $\star * \star \star \star *$ & 0 . & 16. & 0 . & $* * * * *$ & 2.00 & 498.9 \\
\hline APPRO: AS & 47. & -53 & 157. & 2570 . & 68558. & 940. & 2.73 & 499.0 \\
\hline XSID : CODE & XLKQ & XRKQ & & & & & & \\
\hline APPRO: AS & 15. & 40 . & 2919 & & & & & \\
\hline
\end{tabular}

SECOND USER DEFINED TABLE.

$\begin{array}{lcrrrrrrrr}\text { XSID:CODE } & \text { CRWS } & \text { FR\# } & \text { YMIN } & \text { YMAX } & \text { HF } & \text { HO } & \text { VHD } & \text { EGL } & \text { WSEL } \\ \text { EXITX:XS } & 493.70 & 0.56 & 486.67 & 503.17 * * * * * * * * * * * & 0.67 & 496.66 & 495.99 \\ \text { FULLV:FV } & * * * * * * * & 0.60 & 487.19 & 503.69 & 0.28 & 0.05 & 0.76 & 496.98 & 496.22 \\ \text { BRIDG:BR } & 494.75 & 0.98 & 486.20 & 498.91 & 0.45 & 1.19 & 3.45 & 498.30 & 494.85 \\ \text { RDWAY:RG } & * * * * * * * * * * * * * * * & 498.57 & 514.48 & 0.04 * * * * * & 0.18 & 499.13 & 498.99 \\ \text { APPRO:AS } & 492.77 & 0.28 & 487.57 & 505.36 & 0.20 & 0.68 & 0.18 & 499.19 & 499.01 \\ \text { ER } & & & & & & & & & \\ \text { NORMAL END } & \text { OF WSPRO } & \text { EXECUTION. } & & & & & \end{array}$




\section{APPENDIX C:}

\section{BED-MATERIAL PARTICLE-SIZE DISTRIBUTION}




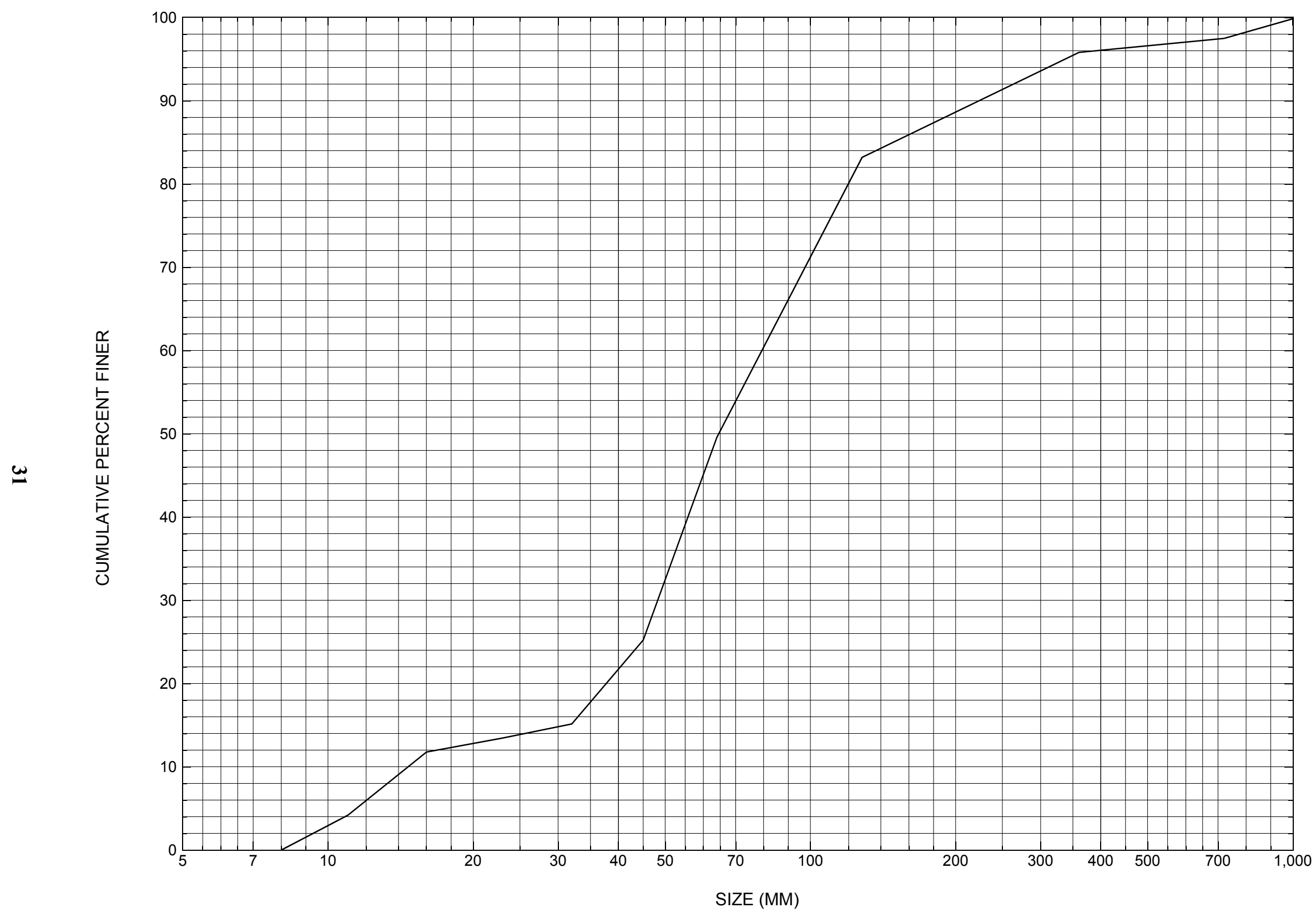

Appendix C. Bed material particle-size distribution for a pebble count in the channel approach of structure CABOTH00410037, in Cabot, Vermont. 


\section{APPENDIX D: \\ HISTORICAL DATA FORM}




\section{Structure Number САВОТН00410037}

\section{General Location Descriptive}

Data collected by (First Initial, Full last name) $\underline{\mathbf{L}}$. Medalie

Date $(M M / D D / Y Y) \_10 / 13 / \underline{95}$

Highway District Number (I - 2; nn) $\mathbf{0 6}$

Town (FIPS place code; I - 4; nnnnn) 11125

Waterway (I - 6) Winooski River

Route Number C3041

Topographic Map Cabot

Latitude (I - 16; nnnn.n) $\mathbf{4 4 2 3 4}$
County (FIPS county code; I - 3; nnn)

Mile marker (I - 11; nnn.nnn) $\underline{\mathbf{0 0 0 0 0 0}}$

Road Name (I - 7):

Vicinity (I - 9) 0.1 MI TO JCT W CL2 TH1

Hydrologic Unit Code: -

Longitude (i - 17; nnnnn.n) $\mathbf{7 2 1 9 8}$

\section{Select Federal Inventory Codes}

FHWA Structure Number (I - 8) $\mathbf{1 0 1 2 0 4 0 0 3 7 1 2 0 4}$

Maintenance responsibility $(I-21 ; n n) \quad \mathbf{0 3} \quad$ Maximum span length $(I-48 ; n n n n) \underline{\mathbf{0 0 2 6}}$

Year built (I - 27; YYYY) 1930

Structure length (I - 49; nnnnnn) $\underline{\mathbf{0 0 0 0 2 9}}$

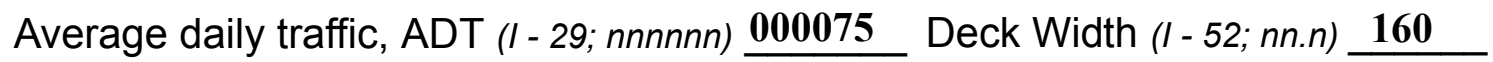

Year of ADT (I - 30; YY) $\underline{\mathbf{9 1}}$

Channel \& Protection $(I-61 ; n) \underline{5}$

Opening skew to Roadway $(I-34 ; n n) \quad \mathbf{0 0}$

Waterway adequacy $(I-71 ; n)$

Operational status $(I-41 ; X)$ A

Underwater Inspection Frequency $(I-92 B ; X Y Y) \_\mathbf{N}$

Structure type (I- 43; nnn) $\mathbf{3 0 2}$

Year Reconstructed (I - 106) $\mathbf{0 0 0 0}$

Approach span structure type (I - 44; nnn) $\mathbf{0 0 0}$

Clear span (nnn.n ft) $\mathbf{2 4}$

Number of spans (I - 45; nnn) $\mathbf{0 0 1}$

Vertical clearance from streambed (nnn.n ft) 9

Number of approach spans (I - 46; nnnn) $\mathbf{0 0 0 0}$

Waterway of full opening (nnn.n $\left.\mathrm{ft}^{2}\right) \mathbf{2 1 6}$

Comments:

According to the structural inspection report dated 10/4/93, the deck of the structure consists of wood planks with wood runners and the decking is untreated lumber. The abutments, wingwalls and backwalls are laid up granite blocks with gravel filled bags making up much of the backwalls on either side of the centerline. New concrete footings have been added on each abutment and on a section of the upstream wingwalls. The Rabut has a concrete cap which has 1" to 2" cracks under 2 of the beams. The laid up stone has small voids overall in both the abutments and wingwalls. The Labut face bulges out at least 6" under the upstream fascia beam. Boulder riprap has been added (continued p. 35) 


\section{Bridge Hydrologic Data}

Is there hydrologic data available? $\underline{\mathbf{N}}$ if No, type ctrl-n $h \quad$ VTAOT Drainage area $\left(m i^{2}\right)$ : -

Terrain character:

Stream character \& type: -

Streambed material:

Discharge Data (cfs):

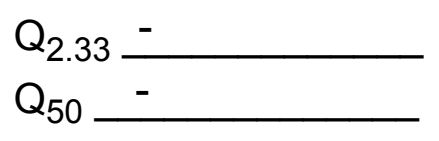

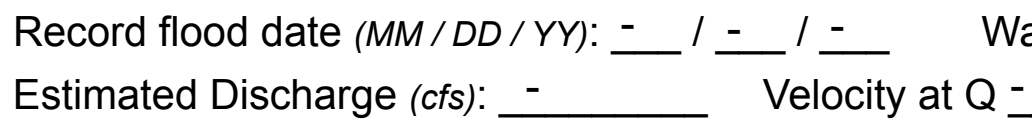

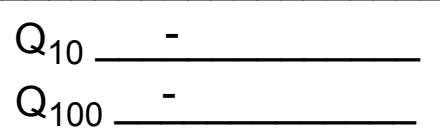

$\mathrm{Q}_{25}$

Water surface elevation $(f t):-$ $(\mathrm{ft} / \mathrm{s}):$

Ice conditions (Heavy, Moderate, Light) : -

Debris (Heavy, Moderate, Light):

The stage increases to maximum highwater elevation (Rapidly, Not rapidly):

The stream response is (Flashy, Not flashy):

Describe any significant site conditions upstream or downstream that may influence the stream's stage: -

Watershed storage area (in percent):

The watershed storage area is: - (1-mainly at the headwaters; 2- uniformly distributed; 3-immediatly upstream oi the site)

Water Surface Elevation Estimates for Existing Structure:

\begin{tabular}{|l|l|l|l|l|l|}
\hline Peak discharge frequency & $Q_{2.33}$ & $Q_{10}$ & $Q_{25}$ & $Q_{50}$ & $Q_{100}$ \\
Water surface elevation (ft)) & - & - & - & - & - \\
Velocity (ft/sec) & - & - & - & - & - \\
\hline
\end{tabular}

Long term stream bed changes: -

Is the roadway overtopped below the $Q_{100}$ ? (Yes, No, Unknown):

Frequency: -

Relief Elevation (ft):

Discharge over roadway at $Q_{100}\left(f^{3} / \mathrm{sec}\right)$ :

Are there other structures nearby? (Yes, No, Unknown): -

Upstream distance (miles):

Town: If No or Unknown, type ctrl-n os

Highway No. : Structure No. : Year Built:

Clear span (ft): Clear Height $(f t)$ : Full Waterway $\left(f^{2}\right)$ : 
Downstream distance (miles): Town: Year Built:

Highway No. : Structure No. : Structure Type:

Clear span (ft): Clear Height $(f t)$ : Full Waterway $\left(f t^{2}\right)$ :

Comments:

along the bottom of the upstream right wingwall, and around the upstream end of the upstream left wingwall.

\section{USGS Watershed Data}

Watershed Hydrographic Data

Drainage area $(D A) \stackrel{21.53}{\mathrm{mi}^{2}}$ Lake/pond/swamp area 0.39 $m i^{2}$ Watershed storage (ST) $\quad \mathbf{1 . 8 2}$

Bridge site elevation 925 $\%$

Main channel length 6.09 $\mathrm{ft}$ Headwater elevation 1831 $\mathrm{ft}$ $10 \%$ channel length elevation $\mathbf{9 5 5}$ $\mathrm{ft} \quad 85 \%$ channel length elevation $\mathrm{ft}$

Main channel slope $(S)$

(S) 105.33 $\mathrm{ft} / \mathrm{mi}$

Watershed Precipitation Data

Average site precipitation in Average headwater precipitation in

Maximum 2yr-24hr precipitation event $(124,2)$ in

Average seasonal snowfall (Sn) $\mathrm{ft}$ 


\section{Bridge Plan Data}

Are plans available? $\mathbf{N} \quad$ If no, type ctrl-n pl Date issued for construction (MM / YYYY):

Project Number

Minimum channel bed elevation:

Low superstructure elevation: USLAB DSLAB USRAB DSRAB Benchmark location description:

No benchmark information is available.

Reference Point (MSL, Arbitrary, Other): Datum (NAD27, NAD83, Other):

Foundation Type: 4

If 1: Footing Thickness

If 2: Pile Type:

If 3: Footing bottom elevation:

Is boring information available? $\mathbf{N}$ Foundation Material Type: $\mathbf{3}$ (1-Spreadfooting; 2-Pile; 3- Gravity; 4-Unknown) Footing bottom elevation: -

Briefly describe material at foundation bottom elevation or around piles:

No foundation material information is available.

Comments:

No bridge plan data is available.
Approximate pile driven length: If no, type ctrl-n bi Number of borings taken: (1-regolith, 2-bedrock, 3-unknown) 


\section{Cross-sectional Data}

Is cross-sectional data available? No If no, type ctrl-n xs

Source (FEMA, VTAOT, Other)? -

Comments: No cross section data is available.

\begin{tabular}{|l|l|l|l|l|l|l|l|l|l|l|l|}
\hline Station & - & - & - & - & - & - & - & - & - & - & - \\
\hline Feature & - & - & - & - & - & - & - & - & - & - & - \\
\hline $\begin{array}{l}\text { Low cord } \\
\text { elevation }\end{array}$ & - & - & - & - & - & - & - & - & - & - & - \\
\hline $\begin{array}{l}\text { Bed } \\
\text { elevation }\end{array}$ & - & - & - & - & - & - & - & - & - & - & - \\
\hline $\begin{array}{l}\text { Low cord } \\
\text { bed length }\end{array}$ & - & - & - & - & - & - & - & - & - & - & - \\
\hline Station & & - & - & - & - & - & - & - & - & - & - \\
\hline Feature & - & - & - & - & - & - & - & - & - & - & - \\
\hline $\begin{array}{l}\text { Low cord } \\
\text { elevation }\end{array}$ & - & - & - & - & - & - & - & - & - & - & - \\
\hline $\begin{array}{l}\text { Bed } \\
\text { elevation }\end{array}$ & - & - & - & - & - & - & - & - & - & - & - \\
\hline $\begin{array}{l}\text { Low cord to } \\
\text { bed length }\end{array}$ & - & - & - & - & - & - & - & - & - & - & - \\
\hline
\end{tabular}

Source (FEMA, VTAOT, Other)?

Comments: -

\begin{tabular}{|l|l|l|l|l|l|l|l|l|l|l|l|}
\hline Station & & - & - & - & - & - & - & - & - & - & - \\
\hline Feature & - & - & - & - & - & - & - & - & - & - & - \\
\hline $\begin{array}{l}\text { Low cord } \\
\text { elevation }\end{array}$ & - & - & - & - & - & - & - & - & - & - & - \\
\hline $\begin{array}{l}\text { Bed } \\
\text { elevation }\end{array}$ & - & - & - & - & - & - & - & - & - & - & - \\
\hline $\begin{array}{l}\text { Low cord to } \\
\text { bed length }\end{array}$ & - & - & - & - & - & - & - & - & - & - & - \\
\hline Station & & - & - & - & - & - & - & - & - & - & - \\
\hline Feature & - & - & - & - & - & - & - & - & - & - & - \\
\hline $\begin{array}{l}\text { Low cord } \\
\text { elevation }\end{array}$ & - & - & - & - & - & - & - & - & - & - & - \\
\hline $\begin{array}{l}\text { Bed } \\
\text { elevation }\end{array}$ & - & - & - & - & - & - & - & - & - & - & - \\
\hline $\begin{array}{l}\text { Low cord to } \\
\text { bed length }\end{array}$ & - & - & - & - & - & - & - & - & - & - & - \\
\hline
\end{tabular}




\section{APPENDIX E: \\ LEVEL I DATA FORM}


U. S. Geological Survey

Bridge Field Data Collection and Processing Form

Qa/Qc Check by: EW

Date: $11 / 6 / 96$

\section{Structure Number}

CABOTH00410037 Date: $\underline{11 / 6 / 96}$ Computerized by: $\underline{\mathbf{E W}}$ Date: $\mathbf{7 / 3 0 / 9 7}$

\section{A. General Location Descriptive}

1. Data collected by (First Initial, Full last name) L. MEDALIE

2. Highway District Number 06

Mile marker $\mathbf{0 0 0 0 0 0}$

County Washington (023)

Town CABOT (11125)

Waterway $(I$ - 6) Winooski River

Route Number C3041

Road Name -

Hydrologic Unit Code: $\mathbf{0 2 0 1 0 0 0 3}$

3. Descriptive comments:

The bridge is located 0.1 miles from the junction with cl 2 th 1 . The bridge deck is wooden.

\section{B. Bridge Deck Observations}
4. Surface cover... LBUS 5
RBUS 5
LBDS 5
RBDS 5
Overall 5

(2b us, ds,lb,rb: 1- Urban; 2- Suburban; 3- Row crops; 4- Pasture; 5- Shrub- and brushland; 6- Forest; 7- Wetland)
5. Ambient water surface... US 2
UB 2
DS 2
(1- pool; 2- riffle)

6. Bridge structure type 1 (1- single span; 2- multiple span; 3- single arch; 4- multiple arch; 5-cylindrical culvert; 6- box culvert; or 7- other)
7. Bridge length 29
(feet)
Span length 26
(feet)
Bridge width 16 (feet)

\section{Road approach to bridge:}
8. LB 0
RB 1
( 0 even, 1- lower, 2- higher)
9. LB_2
RB $\underline{2}$
(1-Paved, 2- Not paved)

10. Embankment slope (run / rise in feet / foot)

US left

US right

\begin{tabular}{|c|c|c|c|}
\hline \multicolumn{2}{|c|}{ Protection } & \multirow{2}{*}{ 13.Erosion } & 14.Severity \\
\hline 11.Type & 12.Cond. & $\mathbf{2}$ & $\mathbf{1}$ \\
\hline $\mathbf{2}$ & $\mathbf{1}$ & $-\mathbf{0}$ & - \\
$\mathbf{0}$ & - & $\mathbf{0}$ & - \\
$\mathbf{0}$ & - & $\mathbf{2}$ & $\mathbf{1}$ \\
\hline $\mathbf{0}$ & - & $\mathbf{0}$ & - \\
\hline
\end{tabular}

Bank protection types: 0- none; 1- < 12 inches,

2- $<36$ inches; $3-<48$ inches;

4- < 60 inches; 5- wall / artificial levee

Bank protection conditions: 1- good; 2- slumped;

3- eroded; 4- failed

Erosion: 0 - none; 1- channel erosion; 2 -

road wash; 3- both; 4- other

Erosion Severity: 0 - none; 1- slight; 2- moderate; 3- severe

\section{Channel approach to bridge (BF):}

15. Angle of approach: $\mathbf{0}$

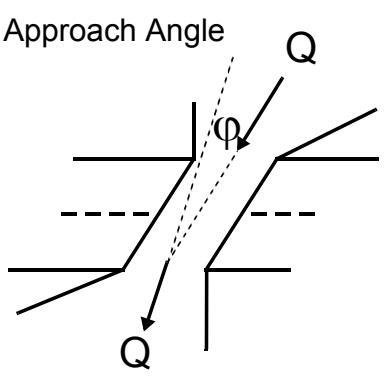

17. Channel impact zone 1 :

Where? LB (LB, RB)

Range? 0 feet US

Channel impact zone 2:

Where? (LB, RB)

Range? feet (US, UB, DS) to feet

16. Bridge skew: 35 Bridge Skew Angle

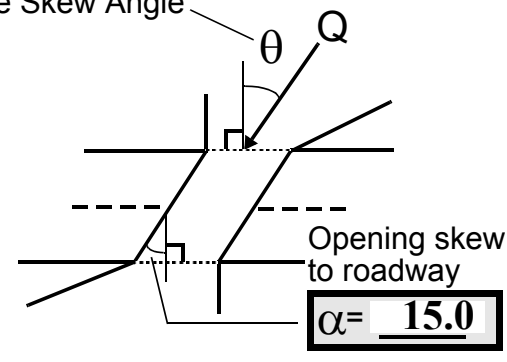

\section{Exist? $\mathbf{Y}(Y$ or $N)$}

Severity 1

(US, UB, DS) to $\underline{\mathbf{3 0}}$ feet $\underline{\mathbf{D S}}$

Exist? $\mathbf{N}(Y$ or $N)$

Severity

Impact Severity: 0- none to very slight; 1- Slight; 2- Moderate; 3- Severe 
18. Bridge Type: $\mathbf{1 b}$

1a- Vertical abutments with wingwalls

1 b- Vertical abutments without wingwalls

2- Vertical abutments and wingwalls, sloping embankment Wingwalls parallel to abut. face

3- Spill through abutments

4- Sloping embankment, vertical wingwalls and abutments

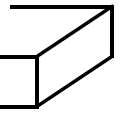

Wingwall angle less than $90^{\circ}$.
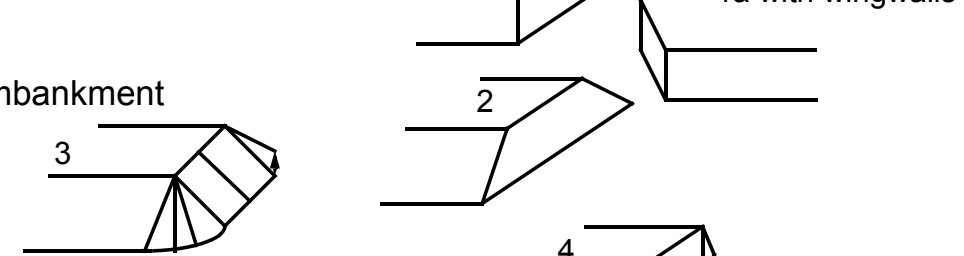

19. Bridge Deck Comments (surface cover variations, measured bridge and span lengths, bridge type variations, approach overflow width, etc.)

4: The upstream left bank is marginal between forest cover and shrub/ brush.

7: Values are from VT AOT. Measured bridge length = 31.6 feet; bridge span = 26.5 feet;

and deck width $=16$ feet (between outside edges).

13: RBDS erosion exists only at the downstream end of the right abutment. LBUS protection consists of only a couple large boulders. Both the RBDS and LBUS have minor erosion with a lot of brush protection to prevent additional erosion.

18: Bridge type is type $1 \mathrm{~b}$ for the upstream left and downstream section of bridge (no wingwalls exist). There is a wingwall extending upstream from the right abutment. The upstream right wingwall blends in with the protection material as it is all laid-up stone. The bridge type for the upstream section is considered to be $1 \mathrm{~b}$ for contraction scour calculations but for abutment scour calculations, the USRWW was considered.

\section{Upstream Channel Assessment}

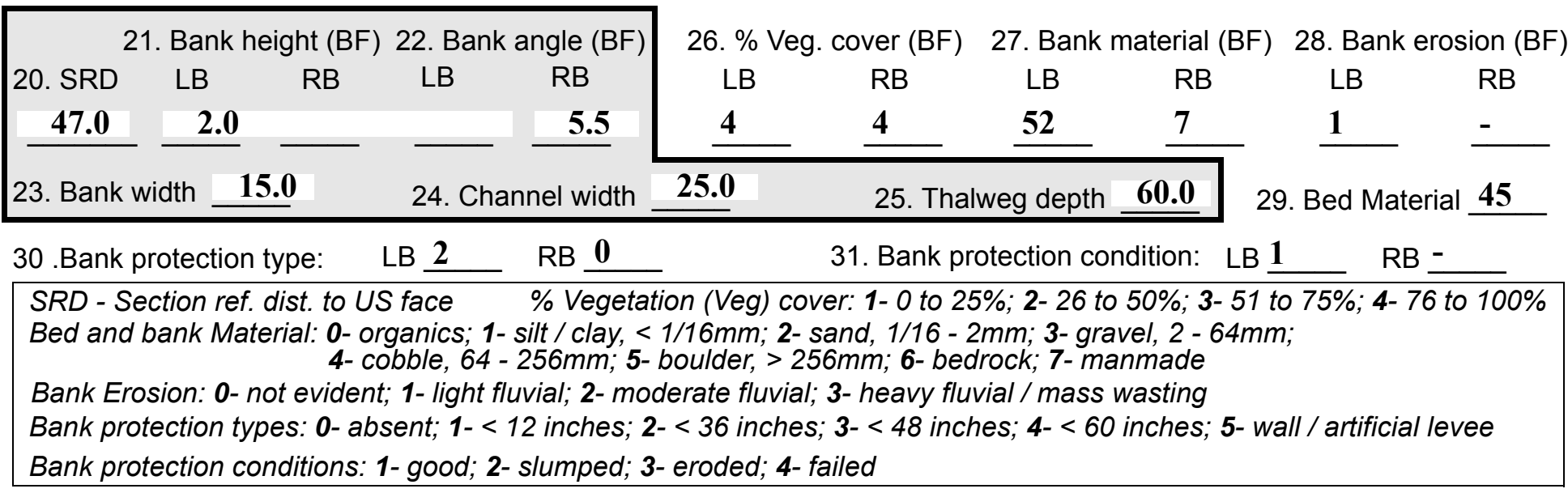

32. Comments (bank material variation, minor inflows, protection extent, etc.):

26: Immediate right bank is $\mathbf{1 0 0 \%}$ covered with brush, although there are no trees.

27: Laid-up stone right wingwall extends to 36 feet upstream.

30: Left bank protection extends from upstream end of LABUT footing at 8 feet upstream to 23 feet upstream.

Along the right bank, beginning at 45 feet upstream, an old mill building extends to 150 feet upstream. Also at 45 feet upstream, the downstream nose of an island comprised of boulders and sand begins which forms a penstock for the old mill. The bank on the bankward side is formed by stones and concrete that are the foundation of the building. There is a stone dam at 250 feet upstream. All measurements were made from the right side of the channel. 
33.Point/Side bar present? $\mathbf{N}(Y$ or $N$. if $N$ type ctrl-n pb)34. Mid-bar distance: -

35. Mid-bar width:

36. Point bar extent: feet (US, UB) to feet (US, UB, DS) positioned $\%$ LB to $\% \mathrm{RB}$

37. Material:

38. Point or side bar comments (Circle Point or Side; Note additional bars, material variation, status, etc.):

NO POINT BARS

39. Is a cut-bank present? $\underline{\mathbf{N}}$ (Y or if $\mathrm{N}$ type ctrl-n cb)

40. Where? (LB or $R B)$

41. Mid-bank distance: -

42. Cut bank extent: feet (US, UB) to feet (US, UB, DS)

43. Bank damage: (1- eroded and/or creep; 2- slip failure; 3- block failure)

44. Cut bank comments (eg. additional cut banks, protection condition, etc.):

NO CUT BANKS

45. Is channel scour present? $\mathbf{N}$ ( $Y$ or if $N$ type ctrl-n cs)

47. Scour dimensions: Length Width Depth : 46. Mid-scour distance: -

48. Scour comments (eg. additional scour areas, local scouring process, etc.):

NO CHANNEL SCOUR

49. Are there major confluences? $\mathbf{N}$

51. Confluence 1: Distance Confluence 2: Distance 52. Enters on Enters on 54. Confluence comments (eg. confluence name):

\section{NO MAJOR CONFLUENCES}

50. How many? -

53. Type(1-perennial; 2- ephemeral)

Type (1-perennial; 2-ephemeral) ( $L B$ or $R B)$

\section{Under Bridge Channel Assessment}

55. Channel restraint (BF)? LB 2

\begin{tabular}{|ccccc}
\hline \multicolumn{2}{|c}{ 56. Height (BF) } & \multicolumn{3}{c}{57 Angle (BF) } \\
LB & RB & LB & RB \\
$\mathbf{4 0 . 5}$ & & & $\mathbf{1 . 5}$ & \\
\hline
\end{tabular}
(1- natural bank; 2- abutment; 3- artificial levee)

58. Bank width (BF) -

59. Channel width -

61. Material (BF)

LB RB

27
62. Erosion (BF)

LB RB

\section{7}

63. Bed Material -

Bed and bank Material: 0- organics; 1- silt / clay, < 1/16mm; 2- sand, 1/16 - 2mm; 3- gravel, 2 - 64mm; 4- cobble, 64 - 256mm; 5- boulder, > 256mm; 6- bedrock; 7- manmade

Bank Erosion: 0- not evident; 1- light fluvial; 2- moderate fluvial; 3- heavy fluvial / mass wasting

64. Comments (bank material variation, minor inflows, protection extent, etc.):

542

63: Sand is along RABUT and boulders (placed protection) are along LABUT at base of footing. 
65. Debris and Ice Is there debris accumulation?

(Yor $N)$ 66. Where? $\mathbf{N}$ (1- Upstream; 2- At bridge; 3- Both)

67. Debris Potential ( 1-Low; 2- Moderate; 3- High)

68. Capture Efficiency 1 (1-Low; 2- Moderate; 3- High)

69. Is there evidence of ice build-up? 2 (Y or $N)$ Ice Blockage Potential $\underline{\mathbf{Y}}$

70. Debris and Ice Comments:

2

67: Not many large trees, but small to medium size trees line the upstream banks.

68/ 69: Small bridge opening.

\begin{tabular}{|l|c|c|c|c|c|c|c|c|}
\hline Abutments & $\begin{array}{c}\text { 71. Attack } \\
\angle \text { (BF) }\end{array}$ & $\begin{array}{c}\text { 72. Slope } \angle \\
\text { (Qmax) }\end{array}$ & $\begin{array}{c}\text { 73. Toe } \\
\text { loc. (BF) }\end{array}$ & $\begin{array}{c}\text { 74. Scour } \\
\text { Condition }\end{array}$ & $\begin{array}{c}75 . \text { Scour } \\
\text { depth }\end{array}$ & $\begin{array}{c}\text { 76. Exposure } \\
\text { depth }\end{array}$ & 77. Material & 78. Length \\
\hline LABUT & & $\mathbf{2 5}$ & $\mathbf{9 0}$ & $\mathbf{2}$ & $\mathbf{2}$ & - & $\mathbf{4}$ & $\mathbf{9 0 . 0}$ \\
\hline RABUT & $\mathbf{2 , 1}$ & $\mathbf{0}$ & $\mathbf{9 0}$ & & & $\mathbf{2}$ & $\mathbf{2}$ & $\mathbf{2 5 . 0}$ \\
\hline
\end{tabular}

Pushed: $L B$ or RB

Toe Location (Loc.): 0- even, 1- set back, 2- protrudes

Scour cond.: 0- not evident; 1- evident (comment); 2- footing exposed; 3-undermined footing; 4- piling exposed; 5- settled; 6- failed

Materials: 1- Concrete; 2- Stone masonry or drywall; 3- steel or metal; 4- wood

79. Abutment comments (eg. undermined penetration, unusual scour processes, debris, etc.):

\section{5}

2,1

71/ 73: Upstream end of left abutment protrudes into the channel more than the downstream end of left abutment. Downstream end of left abutment also acts as bank to 26 feet downstream.

76: The RABUT footing is exposed 2 feet at upstream and downstream ends of footing, and exposure depth is 2.5 feet at the center area of footing.

77: Both abutments are comprised of laid-up stone walls with new concrete footings. Bags filled with concrete

80. Wingwalls:

Exist? Material? Scour Scour Exposure $\begin{array}{lll}81 . & & \\ \text { Angle? Length? }\end{array}$

USLWW: are

USRWW: the

DSLWW: seat

DSRWW: bot-

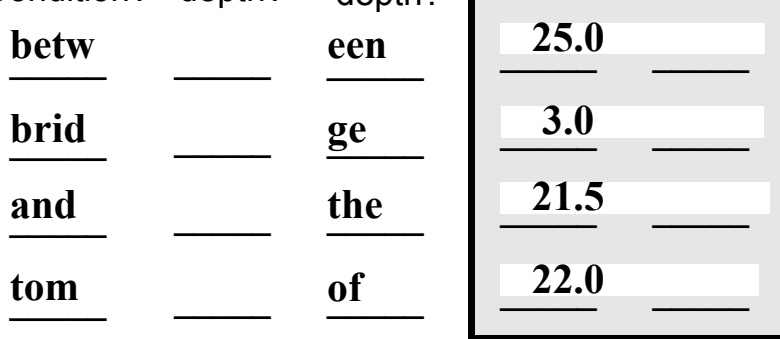

Wingwall materials: 1- Concrete; 2- Stone masonry or drywall; 3- steel or metal; 4- wood

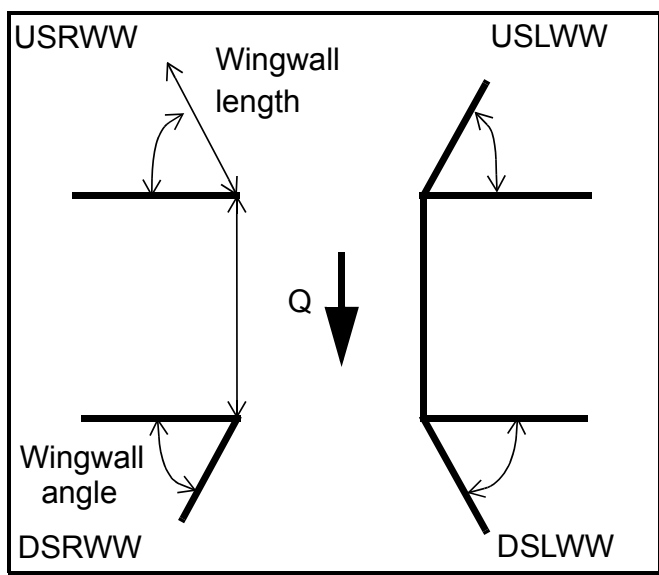

82. Bank / Bridge Protection:

\begin{tabular}{|l|l|l|l|l|l|l|l|l|}
\hline Location & USLWW & USRWW & LABUT & RABUT & LB & RB & DSLWW & DSRWW \\
\hline Type & the & steel & at & of & e & both & ts. & - \\
\hline Condition & brid & bea & the & the & wall & abut & & - \\
\hline Extent & ge & $\mathbf{m s}$ & top & ston & s on & men & N & - \\
\hline
\end{tabular}

Bank / Bridge protection types: 0- absent; 1- 12 inches; 2- < 36 inches; 3- < 48 inches; 4- < 60 inches; 
83. Wingwall and protection comments (eg. undermined penetration, unusual scour processes, etc.):

Y

2

0

$-$

$\mathbf{N}$

$-$

$-$

$-$

Piers:

84. Are there piers? $\mathbf{N} \quad(Y$ or if $N$ type ctrl-n pr)

\begin{tabular}{|l|l|l|l|l|l|l|l|}
\hline \multirow{2}{*}{$\begin{array}{l}85 . \\
\text { Pier no. }\end{array}$} & \multicolumn{3}{|c|}{ width (w) feet } & \multicolumn{3}{c|}{ elevation (e) feet } \\
\cline { 2 - 9 } & w1 & w2 & w3 & e@w1 & e@w2 & e@w3 \\
\hline Pier 1 & - & & & - & $\mathbf{3 5 . 0}$ & $\mathbf{1 8 . 5}$ \\
\hline Pier 2 & - & - & - & - & - & - \\
\hline Pier 3 & - & - & - & - & - & - \\
\hline Pier 4 & - & - & - & - & - & - \\
\hline
\end{tabular}

\begin{tabular}{|l|l|l|l|l|}
\hline Level 1 Pier Descr. & \multicolumn{1}{|c|}{1} & \multicolumn{1}{|c|}{2} & \multicolumn{1}{|c|}{3} & \multicolumn{1}{|c|}{4} \\
\hline 86. Location (BF) & - & $\mathbf{1}$ & - & there \\
\hline 87. Type & - & $\mathbf{0}$ & - & are 5 \\
\hline 88. Material & - & - & - & large \\
\hline 89. Shape & - & - & - & $\mathbf{( 2 . 5}$ \\
\hline 90. Inclined? & - & - & $\mathbf{8 0 :}$ & $\mathbf{f t}$ \\
\hline 91. Attack $\angle$ (BF) & - & - & Alon & diam \\
\hline 92. Pushed & - & - & g the & eter) \\
\hline 93. Length (feet) & - & - & - & - \\
\hline 94. \# of piles & $\mathbf{2}$ & - & upst & boul- \\
\hline 95. Cross-members & $\mathbf{1}$ & - & ream & ders \\
\hline 96. Scour Condition & $\mathbf{1}$ & - & left & stack \\
\hline 97. Scour depth & $\mathbf{2}$ & - & bank & ed \\
\hline 98. Exposure depth & $\mathbf{1}$ & - &, & roug \\
\hline
\end{tabular}

LFP, LTB, LB, MCL, MCM, MCR, RB, RTB, RFP

1- Solid pier, 2- column, 3- bent

1-Wood; 2-concrete; 3- metal; 4- stone

1- Round; 2- Square; 3- Pointed

Y-yes; $N$ - no

$L B$ or $R B$

0- none; 1- laterals; 2- diagonals; 3- both

0- not evident; 1- evident (comment);

2- footing exposed; 3- piling exposed;

4- undermined footing; 5- settled; 6- failed 
99. Pier comments (eg. undermined penetration, protection and protection extent, unusual scour processes, etc.): hly at an angle back from the upstream end of the abutment wall. These 5 boulders extend to 8 feet upstream from the upstream end of the bridge deck. The LABUT extends to 26 feet downstream with no change in angle.

The DSRWW does not exist, but there are stacked cut stones extending back from the RABUT wall at a 90 degree angle, beginning approximately 6 feet from the face of the abutment wall.

82: Right bank protection extends from 4 feet upstream (end of concrete footing) to 38 feet upstream.

100.

\section{E. Downstream Channel Assessment}

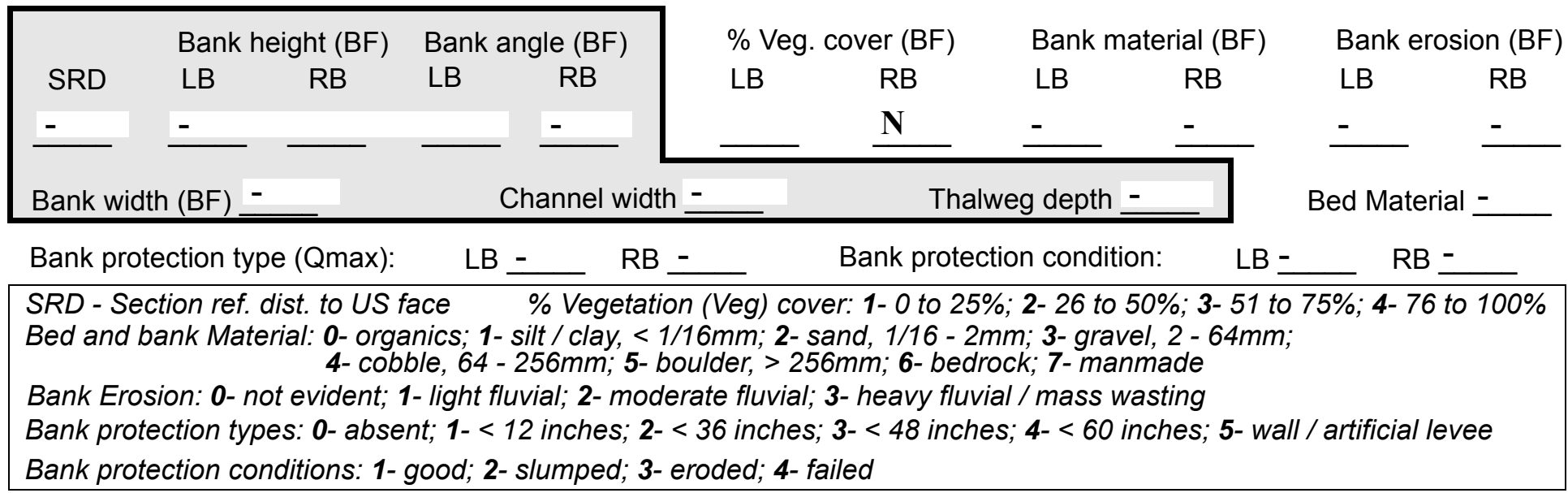

Comments (eg. bank material variation, minor inflows, protection extent, etc.):

$-$

$-$

-

-

-

-

-

-

101. Is a drop structure present? _ ( $Y$ or $N$, if $N$ type ctrl-n ds) 102. Distance: ___ feet 103. Drop: __ feet 104. Structure material: ___ (1- steel sheet pile; 2- wood pile; 3- concrete; 4- other) 105. Drop structure comments (eg. downstream scour depth): 
106. Point/Side bar present? (Y or $N$. if $N$ type ctrl-n pb)Mid-bar distance:

Mid-bar width: -

Point bar extent: feet -

(US, UB, DS) to feet (US, UB, DS) positioned $\%$ LB to $\% \mathrm{RB}$ Material:

Point or side bar comments (Circle Point or Side; note additional bars, material variation, status, etc.):

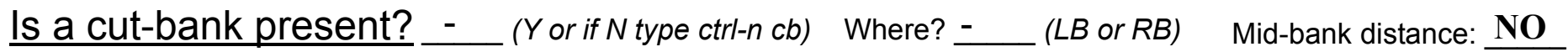
Cut bank extent: $\underline{\text { PIE feet }}$ RS (US, UB, DS) to feet (US, UB, DS)

Bank damage: (1- eroded and/or creep; 2- slip failure; 3- block failure)

Cut bank comments (eg. additional cut banks, protection condition, etc.):

Is channel scour present? Scour dimensions: Length $\underline{2}$ Width 2 (Y or if $N$ type ctrl-n cs)

Mid-scour distance:

Scour comments (eg. additional scour areas, local scouring process, etc.): 1 45

2

2

Are there major confluences? 1 ( $Y$ or if $N$ type ctrl-n $m c)$ Confluence 1: Distance The Enters on $\%$ (LB or $R B)$ How many? 1

Confluence 2: Distance etaEnters on tion (LB or RB) Positioned $\underline{\mathbf{5 2}} \%$ LB to $\underline{\mathbf{0}}$ \%RB Confluence comments (eg. confluence name):

$r$ is type 3 for both banks beyond one bridge length, while it is type-2 within one bridge length.

\section{F. Geomorphic Channel Assessment}

107. Stage of reach evolution
1- Constructed

2- Stable

3- Aggraded

4- Degraded

5- Laterally unstable

6- Vertically and laterally unstable 
108. Evolution comments (Channel evolution not considering bridge effects; See HEC-20, Figure 1 for geomorphic descriptors):

e left bank protection is an extension of the left abutment wall to 26 feet downstream. Beyond that, the left bank is comprised of naturally occurring boulders.

The right bank protection consists of stone block with concrete between and extends from the downstream end of the footing to 18 feet downstream. This block is set in the channel, one foot higher than the current water level. It is approximately 1.5 feet high.

There are a couple of large boulders placed at the right side of the channel at 35 feet downstream. Beyond the boulders, the channel cuts into the right bank to form an eddy area of approximately 20 feet in diameter. It is a small island with trees in the center of eddy area. 


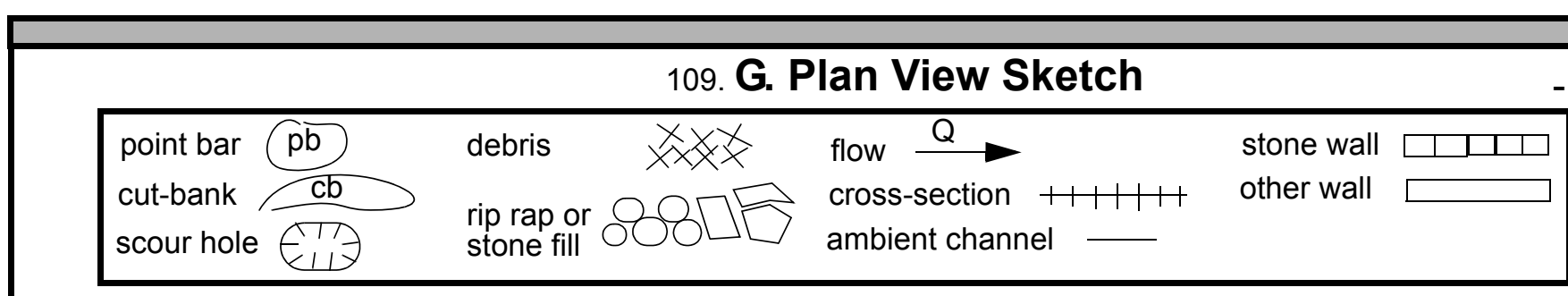


APPENDIX F:

SCOUR COMPUTATIONS 


\begin{tabular}{|c|c|c|c|c|}
\hline $\begin{array}{ll}\text { Structure Number: } & \text { САВОTH00410037 } \\
\text { Road Number: } & \text { TH041 }\end{array}$ & & $\begin{array}{l}\text { Town: } \\
\text { County: }\end{array}$ & $\begin{array}{l}\text { Cabot } \\
\text { Washingt }\end{array}$ & \\
\hline Stream: Winooski River & & & & \\
\hline Initials RHF & Checked: & LKS & & \\
\hline nalysis of contraction scour, li & -bed or $\mathrm{c}$ - & lear wate & & \\
\hline $\begin{array}{l}\text { Critical Velocity of Bed Material } \\
\text { Vc=11.21*y } 1^{\wedge} 0.1667^{*} \mathrm{D} 50^{\wedge} 0.33 \text { with } \\
\text { (Richardson and others, 1995, p. }\end{array}$ & $\begin{array}{l}\text { converted } \\
=2.65 \\
\text { eq. 16) }\end{array}$ & to Eng & sh units) & \\
\hline pproach section & & & & \\
\hline Characteristic & $100 \mathrm{yr}$ & $500 \mathrm{yr}$ & other $\mathrm{Q}$ & other $\mathrm{Q}$ \\
\hline Total discharge, cfs & 3000 & 4100 & 2430 & 2570 \\
\hline Main Channel Area, ft2 & 697 & 741 & 579 & 601 \\
\hline Left overbank area, ft2 & 276 & 351 & 148 & 166 \\
\hline Right overbank area, ft2 & 328 & 402 & 136 & 172 \\
\hline Top width main channel, ft & 60 & 60 & 60 & 60 \\
\hline Top width L overbank, ft & 91 & 112 & 48 & 53 \\
\hline Top width $\mathrm{R}$ overbank, ft & 100 & 101 & 96 & 97 \\
\hline D50 of channel, ft & 0.21177 & 0.21177 & 0.21177 & 0.21177 \\
\hline D50 left overbank, ft & -- & -- & -- & -- \\
\hline D50 right overbank, ft & -- & -- & -- & -- \\
\hline $\mathrm{y} 1$, average depth, $\mathrm{MC}$, ft & 11.6 & 12.4 & 9.7 & 10.0 \\
\hline y1, average depth, LOB, ft & 3.0 & 3.1 & 3.1 & 3.1 \\
\hline y1, average depth, ROB, ft & 3.3 & 4.0 & 1.4 & 1.8 \\
\hline Total conveyance, approach & 99171 & 116333 & 62519 & 68542 \\
\hline Conveyance, main channel & 74064 & 82109 & 54396 & 57922 \\
\hline Conveyance, LOB & 7179 & 9296 & 3849 & 4363 \\
\hline Conveyance, ROB & 17928 & 24928 & 4275 & 6257 \\
\hline Percent discrepancy, conveyance & 0.0000 & 0.0000 & -0.0016 & 0.0000 \\
\hline Qm, discharge, $\mathrm{MC}$, cfs & 2240.5 & 2893.8 & 2114.3 & 2171.8 \\
\hline Q1, discharge, LOB, cfs & 217.2 & 327.6 & 149.6 & 163.6 \\
\hline Qr, discharge, ROB, cfs & 542.3 & 878.6 & 166.2 & 234.6 \\
\hline Vm, mean velocity $\mathrm{MC}$, ft/s & 3.2 & 3.9 & 3.7 & 3.6 \\
\hline $\mathrm{Vl}$, mean velocity, LOB, ft/s & 0.8 & 0.9 & 1.0 & 1.0 \\
\hline Vr, mean velocity, ROB, ft/s & 1.7 & 2.2 & 1.2 & 1.4 \\
\hline Vc-m, crit. velocity, MC, ft/s & 10.1 & 10.2 & 9.7 & 9.8 \\
\hline Vc-l, crit. velocity, LOB, ft/s & $\mathrm{ERR}$ & ERR & ERR & $\mathrm{ERR}$ \\
\hline Vc-r, crit. velocity, ROB, ft/s & ERR & ERR & ERR & $\mathrm{ERR}$ \\
\hline ESULts & & & & \\
\hline Live-bed(1) or Clear-Water(0) Cont & action $\mathrm{Scc}$ & our? & & \\
\hline Main Channel & 0 & 0 & 0 & 0 \\
\hline Left Overbank & $\mathrm{N} / \mathrm{A}$ & $\mathrm{N} / \mathrm{A}$ & $\mathrm{N} / \mathrm{A}$ & $\mathrm{N} / \mathrm{A}$ \\
\hline Right Overbank & $\mathrm{N} / \mathrm{A}$ & $\mathrm{N} / \mathrm{A}$ & $\mathrm{N} / \mathrm{A}$ & $\mathrm{N} / \mathrm{A}$ \\
\hline
\end{tabular}

Armoring

$\mathrm{DC}=\left[\left(1.94 * \mathrm{~V}^{\wedge} 2\right) /(5.75 * \log (12.27 * \mathrm{Y} / \mathrm{D} 90))^{\wedge} 2\right] /[0.03 *(165-62.4)]$

Depth to Armoring $=3 *(1 / \mathrm{PC}-1)$

(Federal Highway Administration, 1993)

$\begin{array}{cllll}\text { Downstream bridge face property } & 100-\mathrm{yr} & 500-\mathrm{yr} & \text { Other Q Other Q } \\ \text { Q, discharge thru bridge MC, Cfs } & 2457 & 2740 & 2430 & 2554 \\ \text { Main channel area (DS), ft2 } & 218 & 245 & 169 & 172\end{array}$ 


\begin{tabular}{|c|c|c|c|c|}
\hline Main channel width (normal), ft & 25.1 & 25.1 & 24.1 & 24.2 \\
\hline Cum. width of piers, ft & 0.0 & 0.0 & 0.0 & 0.0 \\
\hline Adj. main channel width, ft & 25.1 & 25.1 & 24.1 & 24.2 \\
\hline $0, \mathrm{ft}$ & 0.7347 & 0.7347 & 0.7347 & 0.7347 \\
\hline ft & 1.1070 & 1.1070 & 1.1070 & 1.1070 \\
\hline critical grain & 0.5183 & 0.4872 & 0.9210 & 0.9767 \\
\hline Decimal percent coarser th & 0.142 & 0.150 & 0.073 & 0.065 \\
\hline epth to armoring, ft & 9.39 & 8.30 & 35.24 & 41.87 \\
\hline
\end{tabular}

Clear Water Contraction Scour in MAIN CHANNEL

$\mathrm{Y}^{2}=\left(\mathrm{Q} 2^{\wedge} 2 /\left(131 * \mathrm{Dm}^{\wedge}(2 / 3) * \mathrm{~W} 2^{\wedge} 2\right)\right)^{\wedge}(3 / 7) \quad$ Converted to English Units

ys=y2-Y_bridge

(Richardson and others, 1995, p. 32, eq. 20, 20a)

(Q) total discharge, cfs

(Q) discharge thru bridge, cfs

Main channel conveyance

Total conveyance

Q2, bridge MC discharge, cfs

Main channel area, ft2

\begin{tabular}{llll} 
Q100 & Q500 & Other Q & Other Q \\
3000 & 4100 & 2430 & 2570 \\
2457 & 2740 & 2430 & 2554 \\
19832 & 19832 & 13954 & 14376 \\
19832 & 19832 & 13954 & 14376 \\
2457 & 2740 & 2430 & 2554 \\
270 & 270 & 169 & 172 \\
25.1 & 25.1 & 24.1 & 24.2 \\
0.0 & 0.0 & 0.0 & 0.0 \\
25.1 & 25.1 & 24.1 & 24.2 \\
10.76 & 10.76 & 7.01 & 7.11 \\
0.264713 & 0.264713 & 0.264713 & 0.264713 \\
\multicolumn{1}{c}{9.20} & 10.10 & 9.44 & 9.81 \\
-1.56 & -0.65 & 2.43 & 2.71
\end{tabular}

Main channel width (normal), ft
Cum. width of piers in MC, ft

W, adjusted width, ft

Y_bridge (avg. depth at br.), ft

Dm, median $(1.25 * D 50)$, ft

y2, depth in contraction, ft

$-1.56$

$-0.65$

2.43

2.71

Pressure Flow Scour (contraction scour for orifice flow conditions)

Chang pressure flow equation $\quad \mathrm{Hb}+\mathrm{Ys}=\mathrm{Cq} * \mathrm{qbr} / \mathrm{VC}$

$\mathrm{Cq}=1 / \mathrm{Cf} * \mathrm{CC} \quad \mathrm{Cf}=1.5 * \mathrm{Fr}^{\wedge} 0.43(<=1) \quad \mathrm{CC}=\operatorname{SQRT}[0.10(\mathrm{Hb} /(\mathrm{ya}-\mathrm{w})-0.56)]+0.79 \quad(<=1)$

Umbrell pressure flow equation

$(\mathrm{Hb}+\mathrm{Ys}) / \mathrm{ya}=1.1021 *[(1-\mathrm{w} / \mathrm{Ya}) *(\mathrm{Va} / \mathrm{VC})] \wedge 0.6031$

(Richardson and other, 1995, p. 144-146)

Q, total, cfs

Q100

Q, thru bridge

3000

ge, cfs

2457

10.06

Q500

OtherQ

Vc, critical velocity, ft/s

3.21

2740

2430

$\mathrm{Va}$, velocity MC approach, ft/s

Main channel width (normal), ft

25.1

Cum. width of piers in MC, ft

W, adjusted width, ft

0.0

10.16

2430

qbr, unit discharge, ft2/s

Area of full opening, ft2

$\begin{array}{lll}25.1 & 25.1 & 24.1\end{array}$

$97.9 \quad 109.2 \quad 100.8$

$\mathrm{Hb}$, depth of full opening, ft

$270.0 \quad 270.0$

169.0

Fr, Froude number, bridge MC

10.76

10.76

7.01

Cf, Fr correction factor ( $<=1.0)$

0.5

0.55

0

**Area at downstream face, ft2 218

$* \star \mathrm{Hb}$, depth at downstream face, ft

218

1.00

0.00

**Fr, Froude number at DS face

8.69

245

9.76

$\mathrm{N} / \mathrm{A}$

**Cf, for downstream face (<=1.0)

0.67

0.63

$N / A$

1.00

1.00

ERR

Elevation of Low Steel, ft

498.83

498.83

488.07

488.07

Elevation of Approach, ft

Friction loss, approach, ft

500.6

501.34

0.11

0.15

Elevation of WS immediately US, ft

ya, depth immediately US, ft

500.49

501.19

12.42

13.12

Mean elevation of deck, ft

500.25

500.25 


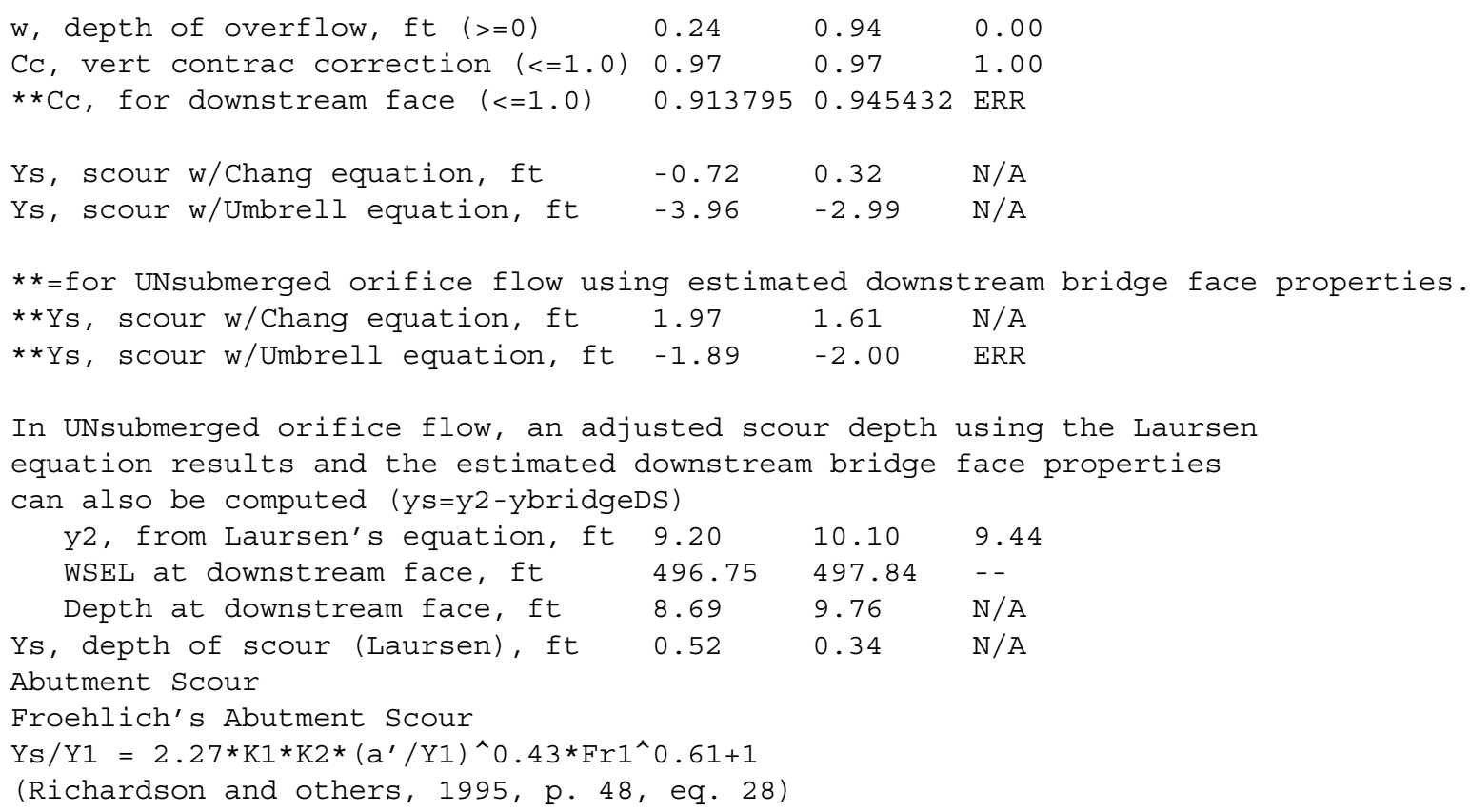

$\begin{array}{llllll}90.9 & 112.6 & 48.7 & 134.2 & 135.6 & 130.9 \\ 3.02 & 2.76 & 3.20 & 4.67 & 4.76 & 3.60 \\ 30.06 & 40.79 & 15.20 & 28.76 & 28.51 & 36.39 \\ 1.03 & 1.03 & 1.03 & 0.95 & 0.95 & 0.95 \\ 0.09 & 0.11 & 0.12 & 0.19 & 0.22 & 0.27 \\ & & & & & \\ 10.34 & 9.86 & \text { ERR } & 18.60 & 19.88 & 16.16 \\ 8.48 & 8.08 & \text { ERR } & 15.25 & 16.30 & 13.25 \\ 5.69 & 5.42 & \text { ERR } & 10.23 & 10.93 & 8.89\end{array}$




\begin{tabular}{|c|c|c|c|c|c|c|}
\hline \multicolumn{7}{|c|}{$\begin{array}{l}\text { Abutment riprap Sizing } \\
\text { Isbash Relationship } \\
\mathrm{D} 50=\mathrm{Y}^{\star} \mathrm{K} \mathrm{Fr}^{\wedge} 2 /(\mathrm{SS}-1) \text { and } \mathrm{D} 50=\mathrm{Y}^{*} \mathrm{~K} *\left(\mathrm{Fr} r^{\wedge} 2\right)^{\wedge} 0.14 /(\mathrm{Ss}-1) \\
\text { (Richardson and others, 1995, p112, eq. 81,82) }\end{array}$} \\
\hline Characteristic & Q100 & Q500 & Other $Q$ & Q100 & Q500 & Other $\mathrm{Q}$ \\
\hline Fr, Froude Number & 0.67 & 0.63 & 0.97 & 0.67 & 0.63 & 0.97 \\
\hline$y$, depth of flow in bridge, ft & 8.69 & 9.76 & 7.01 & 8.69 & 9.76 & 7.01 \\
\hline Median Stone Diameter for ripra] & $=$ : left & outment & & right & abutment, & ft \\
\hline Fr<=0.8 (vertical abut.) & 2.41 & 2.39 & ERR & 2.41 & 2.39 & ERR \\
\hline Fr>0.8 (vertical abut.) & $\mathrm{ERR}$ & ERR & 2.91 & $\mathrm{ERR}$ & ERR & 2.91 \\
\hline Fr<=0.8 (spillthrough abut.) & 2.10 & 2.09 & ERR & 2.10 & 2.09 & ERR \\
\hline Fr>0.8 (spillthrough abut.) & ERR & ERR & 2.57 & ERR & ERR & 2.57 \\
\hline
\end{tabular}

